\title{
Assessment of seawater intrusion to the agricultural sustainability at the coastal area of Carey Island, Selangor, Malaysia
}

\author{
Mohamad Faizal Tajul Baharuddin • Samsudin Taib • \\ Roslan Hashim • Mohd Hazreek Zainal Abidin • \\ Nur Islami Rahman
}

Received: 13 May 2012 / Accepted: 31 July 2012 /Published online: 25 August 2012

(C) Saudi Society for Geosciences 2012

\begin{abstract}
Groundwater suitability for agriculture in an island with limited recharge area may easily be influenced by seawater intrusion. The aim of this study was to investigate seawater intrusion to the suitability of the groundwater for oil palm cultivation at the ex-promontory land of Carey Island in Malaysia. This is the first study that used the integrated method of geo-electrical resistivity and hydrogeochemical methods to investigate seawater intrusion to the suitability of groundwater for oil palm cultivation at two different land cover condition. The relationship between earth resistivity, total dissolved solids and earth conductivity was derived with crop suitability classification according to salinity, used to identify water types and also oil palm tolerance to salinity. Results from the contour conductivity maps show that area facing severe coastal erosion and area still intact with mangrove forest exhibits unsuitable groundwater condition for oil palm at the unconfined aquifer thickness of 15 and $31 \mathrm{~m}$, respectively. Based on local sea-level rise prediction and Ghyben-Herzberg assumption (sharp interface), the condition in the study area, especially in severe erosion area, by the twenty-first century will no longer be suitable for oil palm plantation. The application of geo-electrical method combined with geochemical data,
\end{abstract}

M. F. Tajul Baharuddin $(\bowtie) \cdot$ M. H. Z. Abidin

Department of Water and Environmental Engineering,

Faculty of Civil and Environmental Engineering,

Tun Hussein Onn University,

86400, Batu Pahat, Johor, Malaysia

e-mail:mdfaizal@uthm.edu.my

M. F. Tajul Baharuddin • R. Hashim

Department of Civil Engineering, Faculty of Engineering,

University of Malaya,

50603, Kuala Lumpur, Malaysia

S. Taib · N. I. Rahman

Department of Geology, Faculty of Science, University of Malaya,

50603, Kuala Lumpur, Malaysia aided with the information on environmental history and oil palm physiography, has demonstrated that the integration of techniques is an effective tool in defining the status of agricultural suitability affected by salinity at the coastal aquifer area.

Keywords Oil palm · Groundwater salinity .

Seawater intrusion - Geo-electrical resistivity method .

Contour conductivity map

\section{Introduction}

Agricultural sectors are likely to be most sensitive to climate change, subsequently inducing socioeconomic impact around the world. The Fourth Assessment Report of the Intergovernmental Panel on Climate Change (IPCC 2007) has predicted the impact of climate changes towards crop yield in Asia. Approximately 2.5 to $10 \%$ decrease in crop yield is projected for several parts in Asia in the 2020s, and 5 to $30 \%$ decrease in the 2050 s compared with the conditions during the 1990s. Agricultural productivity in Asia is likely to suffer severe losses because of high temperature, severe drought, flood conditions and soil degradation (IPCC 2007). Climate change is expected to worsen the existing environmental problems along coastal areas. Global mean sea-level rise has been estimated to be between 0.01 and $0.02 \mathrm{~m}$ per year in the last century (IPCC 1996). Future sealevel rise caused by atmospheric climate change is expected to occur at a rate remarkably exceeding that of the recent past. By 2100 , the rise in sea levels is expected to be between 0.2 and $0.8 \mathrm{~m}$ (IPCC 2001). Along with climate change, there is also a concern that future sea-level rise near coastal aquifers may lead to a change in the present hydrogeological boundary and cause more elevated saline groundwater to shift to coastal area (IPCC 2007; Vaeret et al. 2009). 
The relationship between sea-level rise and seawater intrusion can be estimated according to the Ghyben-Herzberg relationship (sharp-interface model). This relationship states that the depth of the interface below the mean sea level is equal to 40 times the height of the potentiometric surface above the mean sea level. Therefore, a $1-\mathrm{m}$ increase in sea level may cause a 40-m reduction in freshwater thickness (Fetter 2002; Hiscock 2005; Abd-Elhamid 2010). When the effect of sea-level rise combines with a huge amount of water requirements for agriculture, the problem becomes very serious. This phenomenon requires practical measures to detect the present status of seawater intrusion into groundwater system, especially in coastal area extensively involved with agricultural activities. Therefore, hydrogeological investigation to assess the status of the groundwater should be conducted to determine groundwater quantity and quality. Three types of methods have commonly been used for seawater intrusion investigations: geochemical methods, geophysical methods and integrated method (Bear and Cheng 2010).

The best geophysical method to assign, particularly in salinity mapping, is geo-electrical method (Loke 2000). Various researchers around the world have applied geoelectrical method in demarcating coastal-area hydrogeology condition, ever since the development of the interpretation technique by Loke and Barker (1996). Electrical resistivity method is unique as it detects increased aquifer conductivity via increased pore-water conductivity (Abdul Nassir et al. 2000). A number of studies have used the geo-electrical method to study seawater intrusion into groundwater aquifers in coastal areas. Edet and Okereke (2001) used the geoelectrical method and geochemical data to examine the extent of seawater intrusion in shallow aquifers (with depths less than $300 \mathrm{~m}$ ) beneath the coastal plains of Southeastern Nigeria. Benkabbour et al. (2004) used the geo-electrical method to characterise seawater intrusion in the Plioquaternary consolidated coastal aquifer of the Mamora Plains in Morocco. Di Sipio et al. (2006) used the geoelectrical method and geochemical data to obtain a better salinity profile of the groundwater system in Venice estuaries. Awni (2006) used the two-dimensional (2D) geoelectrical method to detect sub-surface freshwater and saline water in the alluvial shoreline of the Dead Sea in Jordan. Sherif et al. (2006) integrated the geo-electrical and the hydro-geochemical methods to delineate seawater intrusion in Wadi Ham, UAE. In Lagos, Nigeria, Adepelumi et al. (2009) used the vertical electrical sounding survey to delineate seawater intrusion into the Lekki Peninsula freshwater aquifer. Baharuddin et al. (2009) used the geo-electrical method to study the effect of seawater intrusion and shoreline physical changes in the coastal area of Selangor, Malaysia. Sikandar et al. (2010) used integrated a geo-electrical resistivity survey and geochemistry measurements to investigate groundwater conditions in Pakistan. Sathish et al. (2011) combined the geo-electrical and the geochemical methods to assess the zone of mixing between seawater and groundwater in the coastal aquifer in South Chennai, in Tamil Nadu, India. Ebraheem et al. (2012) conducted a 2D earth resistivity imaging survey in the Wadi Al Bih area in the Northern UAE to determine the potential of the quaternary aquifer and its groundwater quality. Khalil et al. (2012) used the geo-electrical method and time domain electromagnetic method to access seawater intrusion into the groundwater system in the northwestern coast of Egypt.

These studies demonstrate that the geo-electrical method combined with other methods is effective for depicting saline-water boundaries and studying the effects seawater intrusion. The advantages of each of the methods supplement the limitation of the other methods. The most apparent advantage of the combination technique is the reduction in study cost and time without jeopardising the integrity of the data obtained (Maillet et al. 2005; Sathish et al. 2011). In the present study, the combined the geo-electrical and the geochemical methods were implemented, but emphasis was on the present seawater intrusion status and oil palm cultivation at Carey Island, located on the west coast of Peninsular Malaysia. The technique was aided by information related to the environmental history and oil palm physiography. The environmental history discussed in the current work involves the physical changes in the coastal area and the history of agricultural land-use patterns that can influence seawater intrusion distribution at coastal islands.

\section{Hydrology and hydrogeology aspects influence oil palm cultivation at coastal area}

Oil palm (Elaeis guineensis Jacq.) is the most abundant source of oils and fats traded worldwide, accounting for $55.7 \%$ of total exports, followed by soybean oil at $14.7 \%$ (Malaysia Palm Oil Board (MPOB) 2010a). Southeast Asia is currently the dominant region for palm and soybean oil production, with Malaysia being the second largest producer and exporter in the world (39.0 and $45.2 \%$, respectively) after Indonesia (46.4 and $45.3 \%$, respectively) (MPOB $2010 \mathrm{a}, \mathrm{b})$. The palm oil industry supplies a primary commodity and is thus one of the primary sources of income in Malaysia. The industry provides job opportunities and livelihood for over half a million people. This number is estimated to increase to 702,000 people in 2020 (Omar et al. 2010). The industry of palm oil and palm oil-based products contributed $7.5 \%$ (USD 15,853 million) of the nation's gross domestic product in 2009 (Department of Statistic Malaysia 2010). The total area planted with oil palm in Malaysia was approximately $4,853,766$ ha in 2010 . The income from palm oil production provides a lucrative 
monthly income to small-scale farmers from MYR 1,200 to MYR 1,800 $\mathrm{ha}^{-1}$. Due to the lucrative income from palm oil production, this encouraged the small-scale framers, estate plantation and the government to increase the area for oil palm plantation in Malaysia. The palm oil industry is also the main source of income for various developing countries worldwide, including Nigeria, Ivory Coast, Indonesia and other tropical countries. The major importing countries or regions are India, China and European countries, Egypt and Pakistan (MPOB 2010a).

In general, the oil palm requires a warm tropical climate and a high rainfall. Hence, the cultivation of this plant is at present confined to lowland areas of the global humid equatorial regions. The apparent best mean temperature range is 24 to $28^{\circ} \mathrm{C}$. The ideal rainfall pattern is 2,000 to 3,500 mmyear $^{-1}$, evenly distributed throughout the year with a minimum of $100 \mathrm{mmmonth}^{-1}$ (Fairhurst and Hardter 2003). The oil palm has an adventitious root system, that is, with four orders, namely, primary, secondary, tertiary and quaternary. The length of the primary roots system varies by approximately 3 to $6 \mathrm{~m}$, whereas the second roots can penetrate below $1.5 \mathrm{~m}$ (Corley et al. 1976; Williams and Hsu 1979) and can possibly reach the high groundwater table. The amount of available water held in soil (unsaturated zone) is very important for the tertiary and quaternary root systems that cannot extend deeper in the soil. Tinker (1976) estimated that the total length for all root systems is approximately $9,000 \mathrm{kmha}^{-1}$ at usual planting densities. The root system plays an important role for extracting nutrients and water for the germination of an oil palm. All the facts regarding physiography discussed above can cause a significant impact on the hydrology and hydrogeology of oil palm cultivation. Among the hydrological and hydrogeological parameters that influence the oil palm plantations at the coastal area are recharge, evapotranspiration and salinity tolerance. Salinity tolerance is the most important factor in determining the impact of soil salinity to plant suitability and sustainability to grow. A few studies have been conducted in Malaysia to classify plant tolerance towards soil salinity. Wong (1986) introduced the soil-crop suitability classification system for Peninsular Malaysia based on salinity, which is considered as a limitation to crop growth, together with 13 other soil factors. Given the tolerance limits of crops commonly grown in Malaysia, categories, based on electrical conductivity (EC) of soil in the root zone, were proposed and are indicated in Table 1. Another classification was proposed by Mohd. Hashim (2003). To distinguish between degrees of salinity, the EC of the soil in a mixture with water at a ratio of $1: 5$ at $25^{\circ} \mathrm{C}$ was used. The values of EC obtained by this proportion are remarkably smaller than those of the saturated soil extract. Therefore, the limits suggested on the basis of EC of saturated extract correspond to lower values based on the EC of the soil-
Table 1 different degree of salinity, plant tolerance and oil palm tolerance for various electrical conductivity range

\begin{tabular}{|c|c|c|c|}
\hline $\begin{array}{l}\text { EC value } \\
(\mathrm{S} / \mathrm{m})\end{array}$ & $\begin{array}{l}\text { Degree of } \\
\text { salinity, Wong } \\
(1986)\end{array}$ & $\begin{array}{l}\text { Plant tolerance, } \\
\text { Mohd. Hashim } \\
\text { (2003) }\end{array}$ & $\begin{array}{l}\text { Oil palm plant } \\
\text { tolerance, Abd. } \\
\text { Ghani et al (2004) }\end{array}$ \\
\hline$>0.4$ & Severely saline & $\begin{array}{l}\text { Very serious } \\
\text { limitation }\end{array}$ & Not suitable \\
\hline $0.2-0.4$ & $\begin{array}{l}\text { Moderately } \\
\text { saline }\end{array}$ & Serious limitation & Moderately suitable \\
\hline$<0.2$ & Nonsaline & Moderate limitation & Suitable \\
\hline
\end{tabular}

water mixture. The limit proposed for the different degrees of salinity on the basis of the EC of soil-water mixture in the ratio of 1:5 is indicated in Table 1 .

These limits are almost the same as those used in the crop-soil suitability classification system (Wong 1986). Mohd. Hashim (2003) indicated that considering that the system is based on crop tolerance under Malaysian conditions, the limits proposed by Wong (1986) should be acceptable for broader use. Abd. Ghani et al. (2004) mentioned that the suitability of oil palm towards soil salinity at $0.5 \mathrm{~m}$ of soil depth is indicated in Table 1.

The limit for the classification in Table 1 is very similar to that in the study conducted by Wong (1986) and Mohd. Hashim (2003). The soil salinity and oil palm tolerance suggested by Abd. Ghani et al. (2004) can be widely used under Malaysian condition whether for saturated or unsaturated soil. The oil palm is not a halophile species and therefore is not as tolerant to seawater as a coconut plant (Corley and Tinker 2003). When the EC limit exceeds $0.4 \mathrm{Sm}^{-1}$, the oil palm will not be able to tolerate the salinity, eventually leading to the death of the plant (Abd. Ghani et al. 2004).

\section{Materials and methods}

\section{Overview of the study area}

Carey Island, other than being on the west coast of the state of Selangor in Peninsular Malaysia, is separated from the Selangor coast by the Klang River on its north and the Langat River on its east. The island is the largest single island located at the mouth of the Langat River. JICA (2002) reported that the area is located at the Langat River Basin (Fig. 1). The total area of the island is $16,187.45$ ha, representing approximately $6 \%$ of the Langat Basin. The main economic activity of the island is associated with oil palm agricultural products. The land is mostly oil palm plantation $(10,521.84$ ha) (which is approximately $65 \%$ of the total land area of the island) and mangrove forest reserve $(1,876.85 \mathrm{ha})$. The rest is state land and settlements (Golden Hope Plantation Berhad 2006). The study was conducted in the West Estate of Sime-Darby Estate Plantation, 
Fig. 1 Location map of Langat River Basin and Carey Island. Note: Names of villages: 1 and $6=\mathrm{Sg}$. Judah, $2=\mathrm{Sg}$. Rambai, 3 Kenanga, $4=$ Kepau Laut, $5=$ Sg. Bumbun, $7=$ West Estate, $8=$ Sg. Tinggi

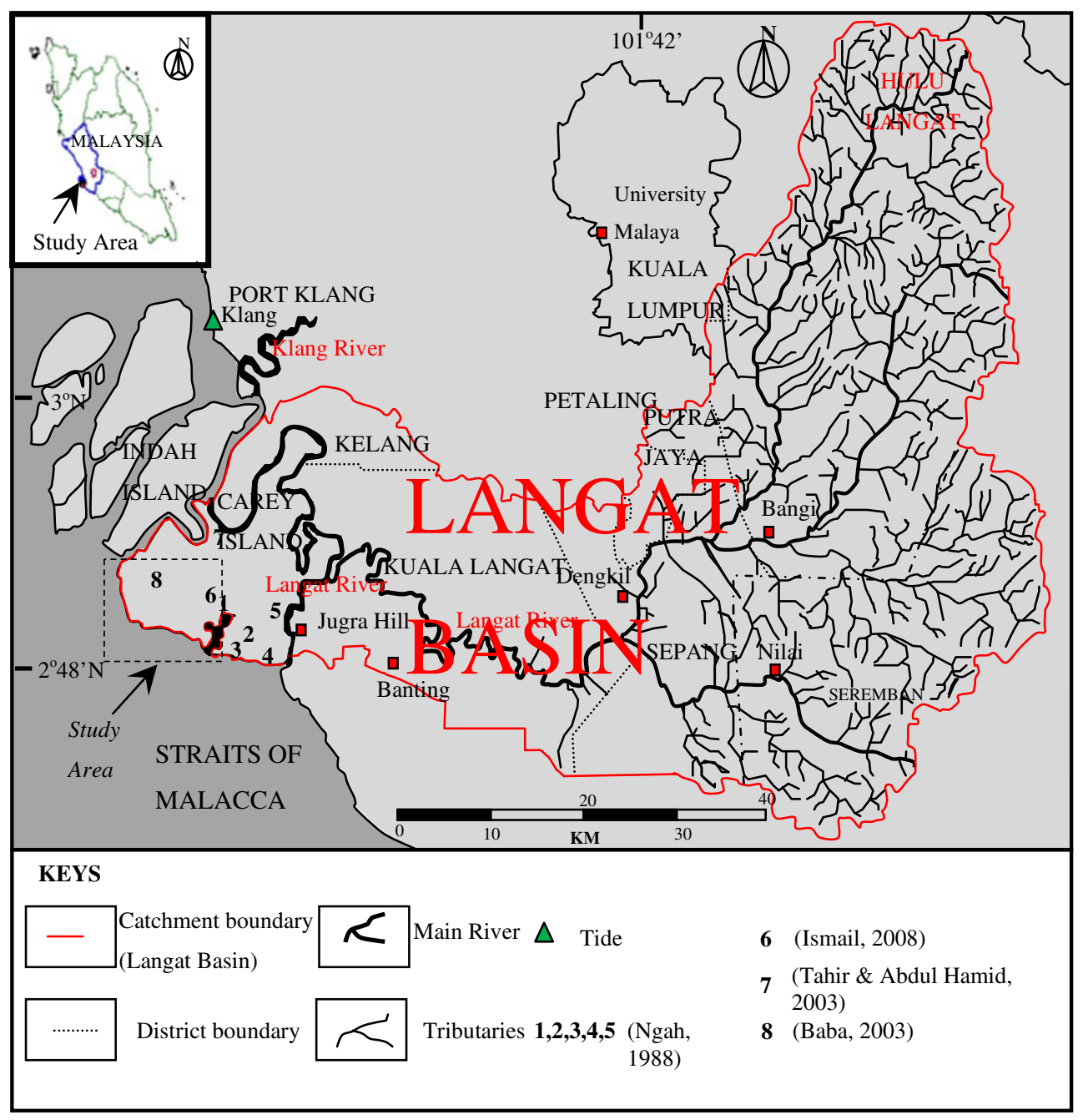

the exact location being the side that faced the Straits of Malacca (Figs. 1 and 2). The total area for the oil palm plantation in the West Estate is 5,016.90 ha where $3,795.45$ ha is producing crops and $1,221.35$ ha is planted with oil palms that are not yet producing any crops (Berita Harian 2011). The average fresh fruit bunch production for the year season of 2009/2010 is 39.7 tha $^{-1}$, the highest yield in Malaysia. This result led to the recognition of the estate from government agency of MPOB in the palm oil industry category as the best production estate with more than 4,000 ha in Peninsular Malaysia. With the production rate of 39.7 tha $^{-1}$, the estimated total income generated by the oil palm plantation for the area can achieve the maximum value of USD 120 million year ${ }^{-1}$.

JICA (2002) reported on the location of the area in the Langat River Basin (Fig. 1), which is hit by the northeast and southwest monsoons annually. The northeast monsoon is from November to March, whereas the southwest monsoon is from May to September. Rainfall intensity varies, most of the rain falling in April and November, with a mean rainfall of $280 \mathrm{~mm}$. The least rain falls in June, with a mean rainfall of $115 \mathrm{~mm}$. Wet seasons are in the transitional periods of the monsoons: March to April and October to November. Monthly rainfall average is $180 \mathrm{~mm}$, whereas annual precipitation is approximately $2,400 \mathrm{~mm}$ (JICA 2002). From analysis of Carey Island's local precipitation events and monthly rainfall data from 2000 to 2010, two seasons can be deduced (Fig. 3): wet (August to December, mean $280 \mathrm{~mm}$ ) and dry (February to March, mean $150 \mathrm{~m}$ ).

Vegetation pattern impact

Before the early 1900s, most of the island, especially in the coastal areas, was a mangrove swamp. Golden Hope Plantation Berhad (2006) reported that the location of Carey Island is the thickest belt of the coastal swamp where most of the land was mud and mangrove. The land-use history of the island is inextricably linked to expansions into the Malaysia Peninsula, British colonial interests and the European plantation industry. Carey opened Carey Island in the early 1900s and cultivation of rubber then oil palm expanded in the same area. Another crop hugely cultivated was 
Fig. 2 Locations of monitoring wells, resistivity survey lines, drainages system and boundary between unconfined and semiconfined aquifers

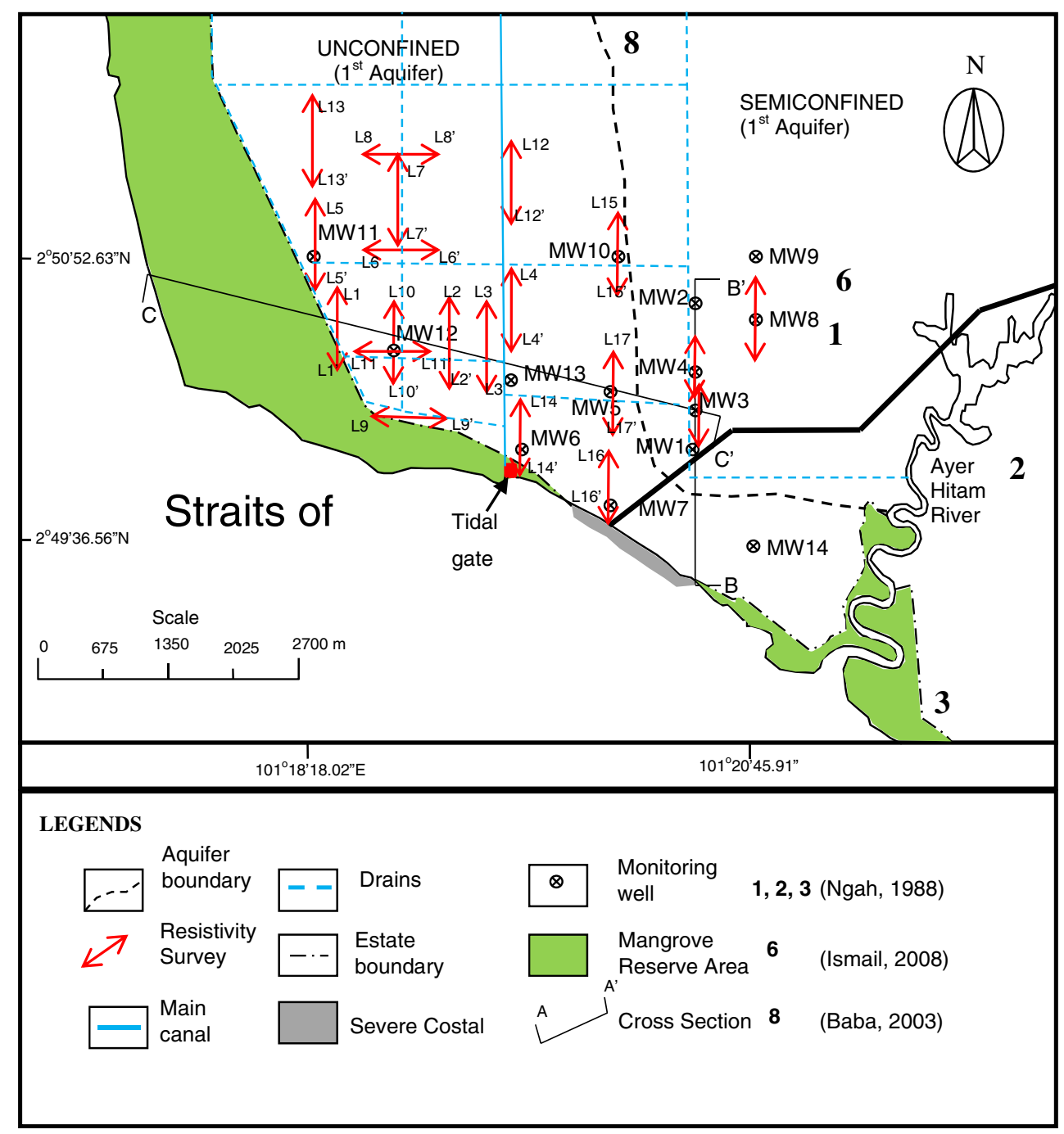

coconut, which the earliest strategies placed at the newly cleared mangrove along the coastal belt. The coconuts were planted immediately landward of the mangrove line where the tidal mangroves were retained. Jungle areas towards the
Fig. 3 Dry and wet seasons deduced from analysis of Carey Island's 2000-2010 monthly rainfall data

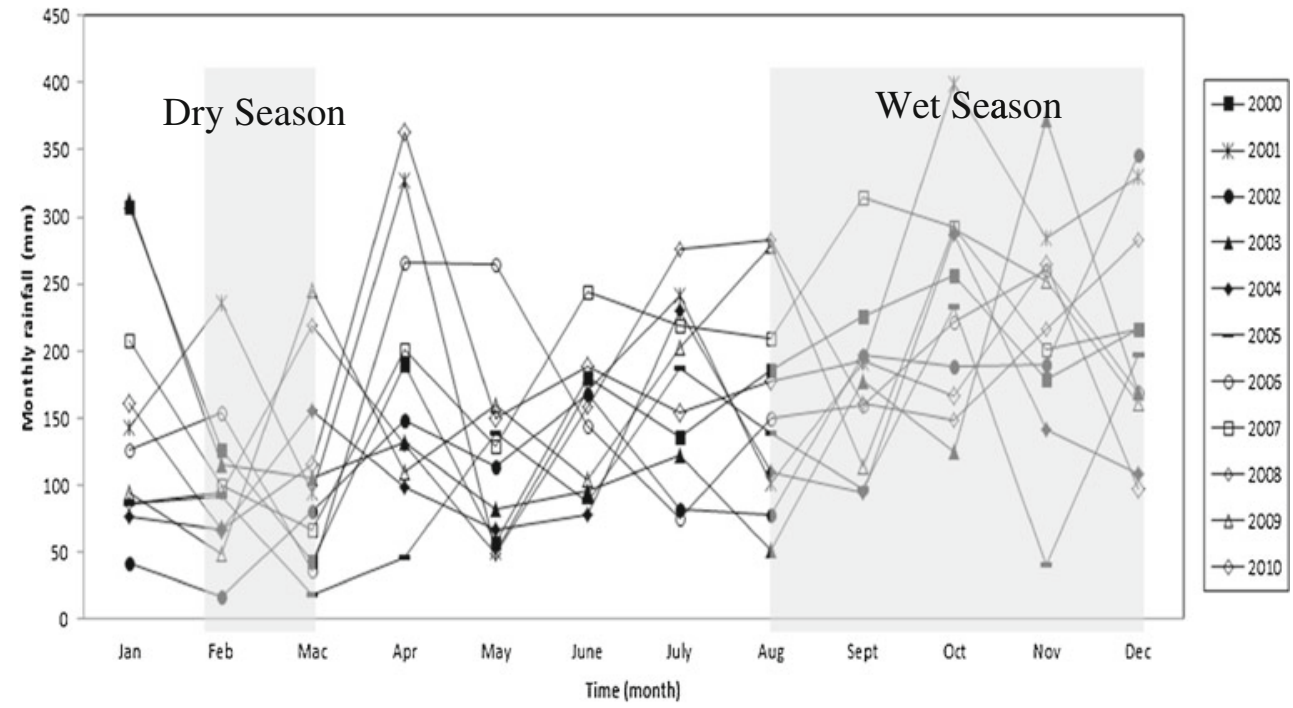


centre of the island were reserved for rubber. By the 1920s, a total of 2,630 ha had been planted with coconut and 4,249 ha with rubber. When the rubber-planting trend was temporarily halted in the early 1920 s, approximately 1,214 ha were planted with coconuts. Tea was another crop that changed land use in North and West Carey Island, covering 470 ha. From 1955 onwards, all the crops (tea, coconut, rubber) were replaced by oil palm.

The approximate land use of Carey Island compared between that on the topography map published by the Department of Survey and Mapping Malaysia in 1974 and that on the Google 2010 map is shown in Fig. 4. The opening of the agricultural land in the island significantly deforested mangroves, especially in the south situated in the study area. The size of the mangrove deforestation was determined by observation and comparison between previous and current maps. Mangrove stumps were found up to $300 \mathrm{~m}$ seaward of the present shoreline, indicating large-scale deforestation (Affandi et al. 2010). Loss of mangrove area in the southern area is estimated to be 2,844 ha, comparing the 1974 map with the present one. According to Affandi et al. (2010), deforestation of the mangroves trees was caused by frequent seawater waves from SW (during the southwest monsoon) and $\mathrm{W}$ (during the northeast monsoon). The site is exposed to direct wave action, very unfavourable for mangrove establishment. Assuming the island was all covered by mangroves $(16,187.45$ ha before the 1900 s and from the present forest reserve area of the mangrove (approximately $1,876.85 \mathrm{ha})$ ), the estimated percentage of mangroves lost to agricultural activities, residential area development and strong current wave action is $88 \%$. Hence, the geomorphological changes in the agricultural land use in Carey Island are assumed to have been detrimental to precious growth of the mangroves from inward to seaward. Seawater wave action that had steadily been eroding the soil triggered the disappearance of the mangroves from the coast. Human activity has caused further damage to the mangrove area.

\section{Hydrogeology area}

Suntharalingam and Teoh (1985) reported on the underlying Holocene-age marine sediments existing in the area over most of coast in West Peninsular Malaysia referred to as the Gula Formation. The sediments comprise grey clay and

Fig. 4 Carey Island's land use, in 1974 and in modern day (note the large area covered by palm oil trees in modern day; mangrove deforestation exposed the coastal area; the large palm oil cultivation area in the south is present day)

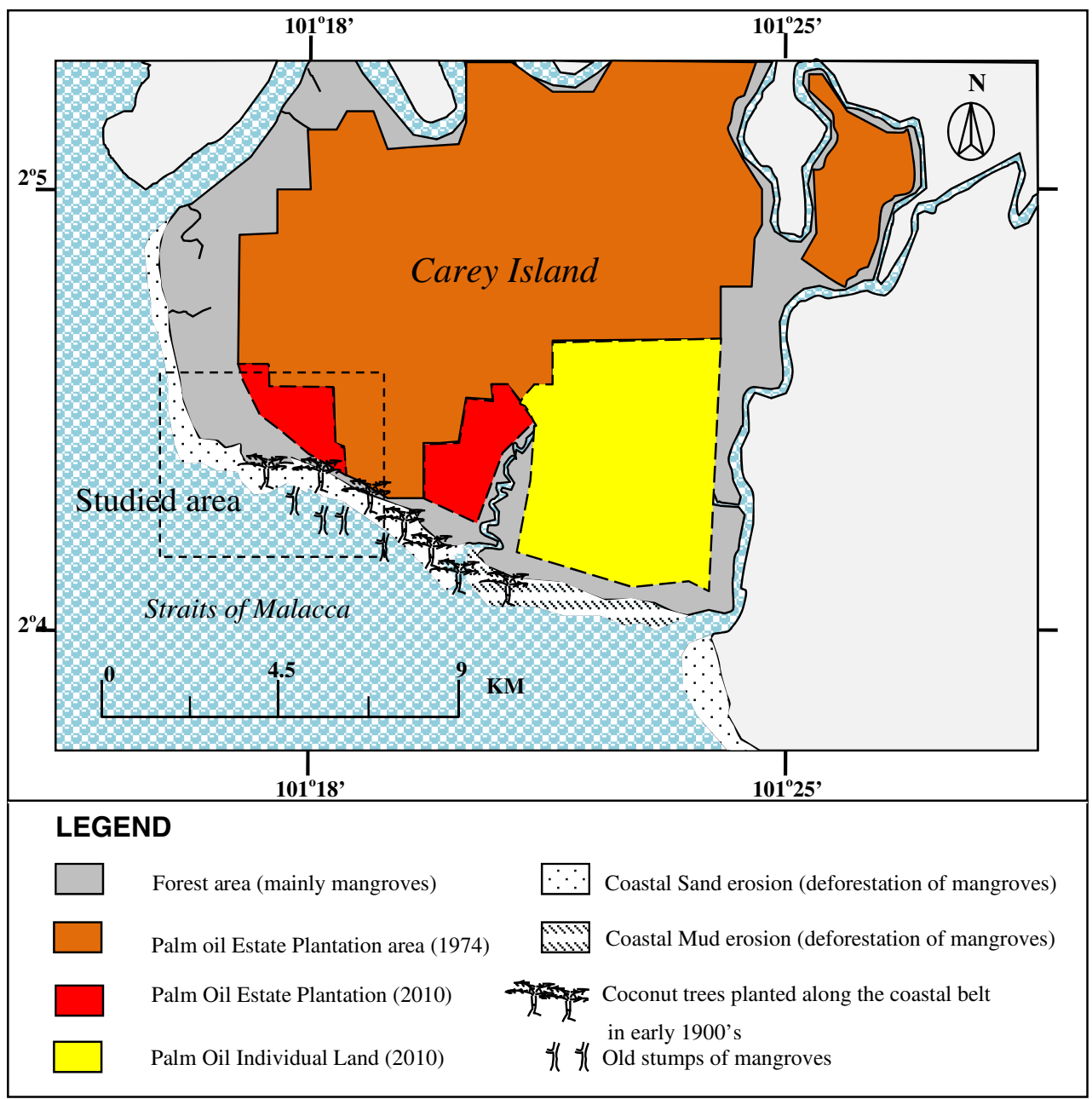


sand, minor gravel with traces of fragmented shells and peaty materials. There is no indication of exposed outcrop on the island, except for a granitic rock outcrop at Jugra Hills by the Langat River. Studies by Tahir and Abd Hamid (2003), Baba (2003) and Ismail (2008), on wells 96 to $185 \mathrm{~m}$ deep showed that the aquifers in this island are semi-confined. Other studies have yet to explain the hydrogeology work done west of the area (Figs. 1 and 2).

To investigate sub-surface profiles of the coastal alluvium, 14 monitoring wells (MW1 up to MW14) with depths of 40,50 and $80 \mathrm{~m}$ were constructed between March and May 2009, filling gaps left by preceding studies. The wells faced the Straits of Malacca where direct hit of saltwater was assumed (Fig. 2). Rotary wash boring was used to drill the boreholes, and soil samples were collected for visual examination, as well as laboratory test experiments (BS1377 1990), to determine physical properties. The classification of grain size of sand was based on BS 1377 (1990) (fine sand 0.063 to $0.1 \mathrm{~mm}$, medium sand 0.1 to $0.4 \mathrm{~mm}$ and coarse sand 1 to $2 \mathrm{~mm}$ ). Sandy soil samples were collected using a split spoon embedded with spring-core catcher, which trapped sand in the barrel of the split spoon. Recovery ratio of the disturbed sandy soil samples was more than $80 \%$ during the borehole sampling. Tests for physical properties were for particle-size distribution, Atterberg limit, moisture content, specific gravity and linear shrinkage. Well development proceeded after the wells had been constructed, with bailer and suction pump removing trapped sediments so that desirable data for groundwater quality and quantity could be acquired.

\section{Groundwater monitoring}

Groundwater monitoring was done once or twice a week, starting August 2009 until March 2011. Groundwater samples were collected from the monitoring wells by using a bailer. Physical parameters such as conductivity, salinity, total dissolved solids (TDSs) and temperature were measured by using the precision equipment EC300 YSI immediately after sampling. The equipment was calibrated against a standard potassium chloride $(\mathrm{KCl})$ solution of $1.411-\mathrm{mS} / \mathrm{cm}$ conductivity. Groundwater tables also were recorded during the groundwater sampling. Hydrogeochemical parameters measured were major cations and anions. Collected groundwater samples were divided and kept in two containers. For cation analysis, the groundwater samples were filtered by a Whatman 42 filter paper and preserved with $2 \%$ nitric acid $\left(\mathrm{HNO}_{3}\right)$. For anion analysis, the groundwater samples were filtered and then preserved at a maintained $4{ }^{\circ} \mathrm{C}$. The anion analysis was done within $48 \mathrm{~h}$ of collection time. Cations analysed were sodium $(\mathrm{Na})$, calcium $(\mathrm{Ca})$, magnesium $(\mathrm{Mg})$, potassium $(\mathrm{K})$ and iron $(\mathrm{Fe})$, on the PerkinElmer inductive coupled plasma optical emission spectrometer model Optima 3300RL. Anions analysed were chloride $\left(\mathrm{Cl}^{-}\right)$, sulphate $\left(\mathrm{SO}_{4}{ }^{2-}\right)$, nitrate $\left(\mathrm{NO}_{3}{ }^{-}\right)$ and bromide $\left(\mathrm{Br}^{-}\right)$, on Dionex ion chromatography model ICS2000. The analyses were done to standard methods (APHA 2005), a five-point calibration quantifying the analyses with correlation coefficient of the calibration curve between 0.995 and 0.999 . Water classification was based on Fetter (2002), and three types were identified: saline $(\mathrm{TDS}>10,000 \mathrm{mg} / \mathrm{l})$, brackish $(1,000<\mathrm{TDS}<10,000 \mathrm{mg} / \mathrm{l})$ and fresh (TDS $<1,000 \mathrm{mg} / \mathrm{l}$ ).

\section{Resistivity surveys}

The strategy for conducting the resistivity surveys to assess the environmental impact caused by seawater intrusion was planned to have two phases. The first phase involved the finding of correlation between sub-surface earth resistivity and geochemical data from monitoring wells. Groundwater samples were collected using a bailer. Physical parameters, such as conductivity, salinity, TDS and temperature, were measured using the precision equipment EC300 YSI immediately after sampling. The equipment was calibrated against a standard potassium chloride solution of $1.411 \mathrm{~m}$ $\mathrm{Scm}^{-1}$ conductivity (APHA 2005). The second phase involved an extensive resistivity survey in the area of severe erosion and the area still intact with the mangrove trees. The locations of resistivity lines are shown in Fig. 2.

Geo-electric survey was conducted using the ABEM Terrameter SAS4000 combined with the ES10-64 electrode selector. Electrical resistivity measurements were performed four times, as follows: August 2009, November 2009, February 2010 and December 2010. Electrical resistivity measurements in August 2009, November 2009 and February 2010 were used to identify the correlation between sub-surface resistivity and geochemical data. Nine resistivity image profiles were measured across the nine monitoring wells (Fig. 2).

In December 2010, 17 resistivity image profiles were measured to extensively map the sub-surface resistivity at the site covered with mangrove and erosion areas. For each profile, 61 electrodes were pegged $5 \mathrm{~m}$ apart and connected to the cable joined to the ES10-64 electrode selector along $400 \mathrm{~m}$ of ground surface. The survey line traverses were oriented N-S and W-E. The Wenner array was chosen for the resistivity traverses because this method gives a dense nearsurface cover of resistivity data. This method also provides (as horizontal structures) good vertical resolution and clear images of groundwater, saltwater intrusion and sand-clay boundaries (Hamzah et al. 2006). Data gathered were interpreted by the RES2DINV software of Loke et al. (2003) that provided an inverse model that approximated actual subsurface resistivity distribution. The program is divided into a number of rectangular blocks and the two-dimensional model used in the sub-surface (Loke and Barker 1996). 
To minimise the difference between measured and calculated apparent resistivity values, the resistivity values of the blocks were adjusted iteratively. Calculation was according to the finite-difference method of Dey and Morrison (1979). Resistivity field data collected through Wenner array from individual survey lines were inverted individually to generate a two-dimensional Wenner resistivity model. The inversions were performed on an AMD Athlon ${ }^{\mathrm{TM}} 64$ X2 DualCore Processor TK-57 1.90 GHz with 3.00-GB RAM. An initial model was produced, from which a response was calculated and compared with the measured data. The model was then modified to reduce the differences between response and data. Differences were quantified as rootmean-square (RMS) errors. The process continued iteratively until the RMS error fell to within acceptable limits, usually below $5 \%$, or until change between RMS values calculated for consecutive iterations became insignificant (Awni 2006). The model with the lowest possible RMS error, however, is not always the most appropriate one as this value can show unrealistic variations in the resistivity model (Loke 2010b). Finite-difference method was used as the data did not include topography. Given the near flatness of the site, the resistivity models were not significantly affected by topography. Two-dimensional inversion techniques are common and often acceptable in assessing resolution and in determining data-set limitations (Dahlin and Loke 1998). Resistivity of fresh groundwater varies from 10 to $100 \Omega \mathrm{m}$ depending on dissolved-salt concentration. The low resistivity $(<0.2 \Omega \mathrm{m})$ of seawater is due to its high salt content (Loke 2010a), making the resistivity method an ideal technique for mapping of saline-freshwater interface. Note that the resistivity of alluvium ranges from 10 to $800 \Omega$ $\mathrm{m}$ depending on soil type. The results of sub-surface resistivity values in December 2010 were interpolated as an estimation of conductivity map area using Surfer8.

\section{Results}

Sub-surface hydrogeology

Analysis of the monitoring wells' borelogs shows the area's lithology as being quaternary alluvium sediments reaching beyond $80 \mathrm{~m}$ depth. Quaternary alluvium sediments comprise alternating layers of gravel, sand, silt and clay. Figures 5, 6 and 7 are cross sections of the area's hydrogeology. Two aquifers were found $80 \mathrm{~m}$ down in the quaternary sediments. At distances up to $1.5 \mathrm{~km}$ from shoreline, the first aquifer, 10 to $60 \mathrm{~m}$ deep, was categorised as unconfined. Beyond $1.5 \mathrm{~km}$, the first aquifer showed semi-confined characteristics. From the 14 monitoring wells constructed within the area, the first unconfined aquifer was identified via analyses of borelogs at MW5, MW6, MW7, MW10, MW11, MW12, MW13 and MW14
(Figs. 6 and 7). This aquifer had fine-to-medium lightgrey sand and occasional instances of coarse sand and gravel, impermeable materials (silt and clay) and shell fragments (whose presence confirmed the deposition of the layer by a marine environment, i.e. Gula Formation, Fig. 7). Thicknesses of the first unconfined aquifers ranged from $10 \mathrm{~m}$ to $40 \mathrm{~m}$.

Borelog information for MW1, MW2, MW3, MW4, MW8 and MW9 showed the presence of semi-confined aquifers. In the first semi-confined aquifer, the thickness of the uppermost semi-impermeable layer varied from 27.00 to $31.50 \mathrm{~m}$ below ground surface. The soil was light grey, marine and silty clay. The semi-impermeable layer overlying the first semi-confined aquifer comprised fine-to-coarse light-grey sand and gravel. Thicknesses of the semiconfined aquifers ranged approximately from 20 to $30 \mathrm{~m}$ (Figs. 5 and 6). Borelog information from MW1 and MW2 (Figs. 5 and 6) showed the depth of the first semi-confined aquifer reaching between 60 and $66 \mathrm{~m}$. The first semiconfined aquifer overlay a thin semi-impermeable layer 3to 5-m thick, separating the first semi-confined aquifer from the second semi-confined aquifer (Figs. 5 and 6). The thickness of the second semi-confined aquifer was unknown because of the borehole-depth limit. Existence of freshwater lens at the island was noted at a shallow semi-confined aquifer (Ngah 1988). The boundary between the unconfined and semi-confined aquifers in the area is shown in Fig. 2 that was determined by the borelog data obtained from Ngah (1988) and present study. There had not been groundwater extraction for domestic or economic uses that could have affected the area's rapid fluctuation of groundwater table.

\section{Sources of salinity}

The samples were analysed for major cations and anions. The cations analysed were sodium $(\mathrm{Na})$, magnesium $(\mathrm{Mg})$, calcium $(\mathrm{Ca})$, potassium $(\mathrm{K})$ and iron $(\mathrm{Fe})$. The anions were chloride $\left(\mathrm{Cl}^{-}\right)$, sulphate $\left(\mathrm{SO}_{4}{ }^{2-}\right)$, nitrate $\left(\mathrm{NO}_{3}{ }^{-}\right)$, bromide $\left(\mathrm{Br}^{-}\right)$and fluoride $\left(\mathrm{F}^{-}\right)$. Table 2 lists the results. $\mathrm{Na}$ and $\mathrm{Cl}^{-}$ exceeded $70 \%$ of the measured TDSs. Dominant contents of $\mathrm{Na}$ and $\mathrm{Cl}$ showed that seawater intrusion was the source of salinity (Samsudin et al. 2008; Pujari and Soni, 2008). Conductivity measurement of groundwater showed values exceeding $5 \mathrm{mS} / \mathrm{cm}$ (Table 2) where it showed that groundwater in this area is affected by seawater as stated by Aris and Mohd Isa (2012). Hence, seawater intrusion was confirmed as the causing of the site salinity.

Groundwater tables and TDS controlling hydrology and hydrogeology aspect

Figures 8 and 9 show the groundwater levels and TDS value from monitoring wells at the unconfined aquifers in the 


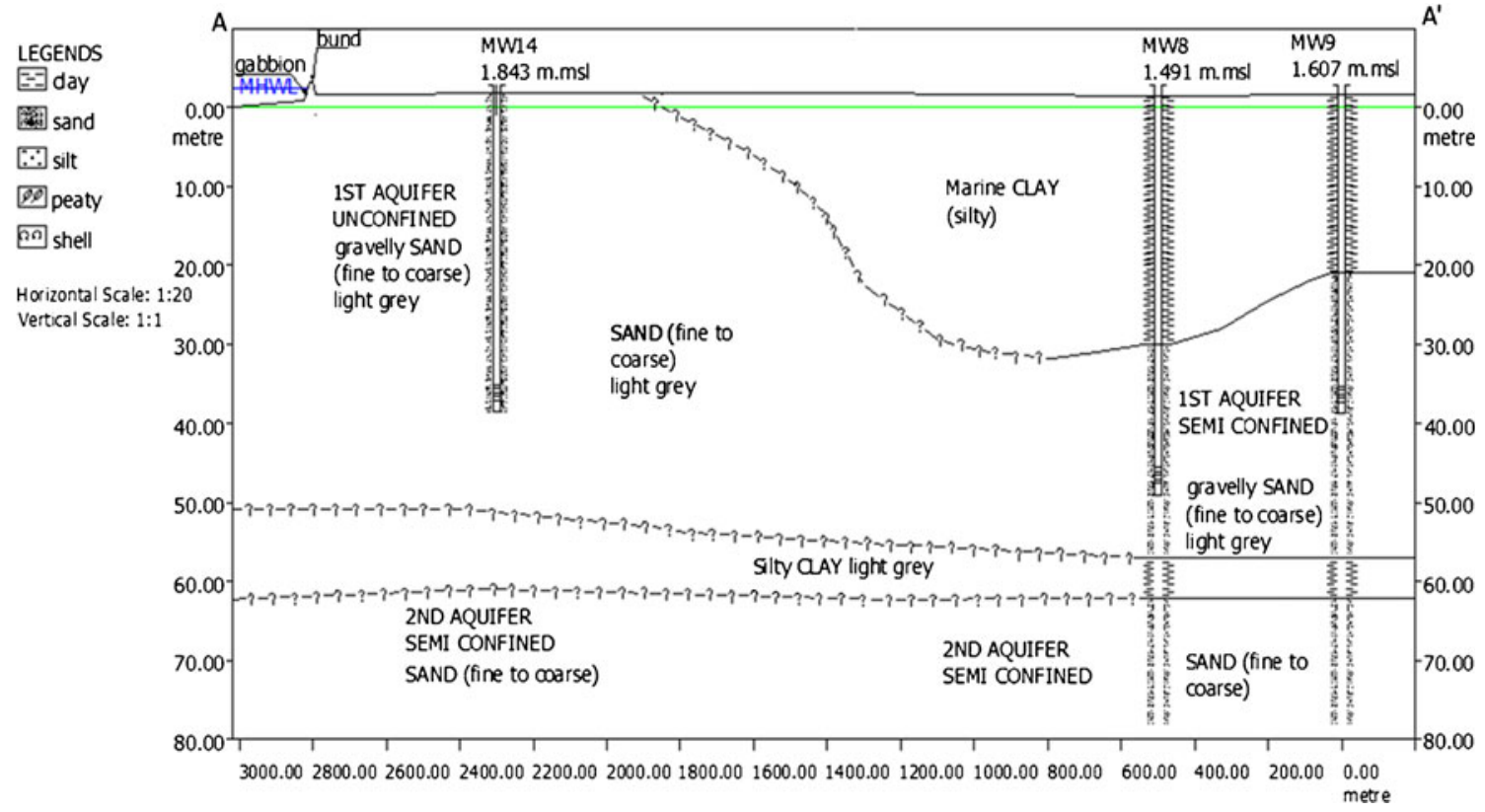

Fig. $5 A-A^{\prime}$ Cross section of the studied area's sub-surface profile showing unconfined and semi-confined aquifers

study area. The groundwater levels increased in the wet season and decreased in the dry season. This result showed that the unconfined more quickly responded to local seasonal conditions than to the Langat Basin seasonal conditions as mentioned by JICA and DMGM (2002). Hence, the groundwater recharge at the site completely relied on local precipitation rather than on the base flow from the mainland.

To define the relationship between groundwater quality and quantity in the study area, data on the groundwater tables and TDS were collected from long-term groundwater monitoring of areas with unconfined aquifer in both southeast (characterised by severe coastal erosion) and northwest (containing preserved mangrove) areas. Three monitoring wells, namely, MW11, MW12 and MW13, and another three, namely, MW5, MW7 and MW10, were chosen from the northwest and the southeast areas, respectively. Other wells were located outside these settings and in the semi-confined aquifer areas with different screen level depths. The six monitoring wells were constructed with the same depth $(40 \mathrm{~m})$ and opening screen for water at depth of 34 to $36 \mathrm{~m}$. A study of the correlation

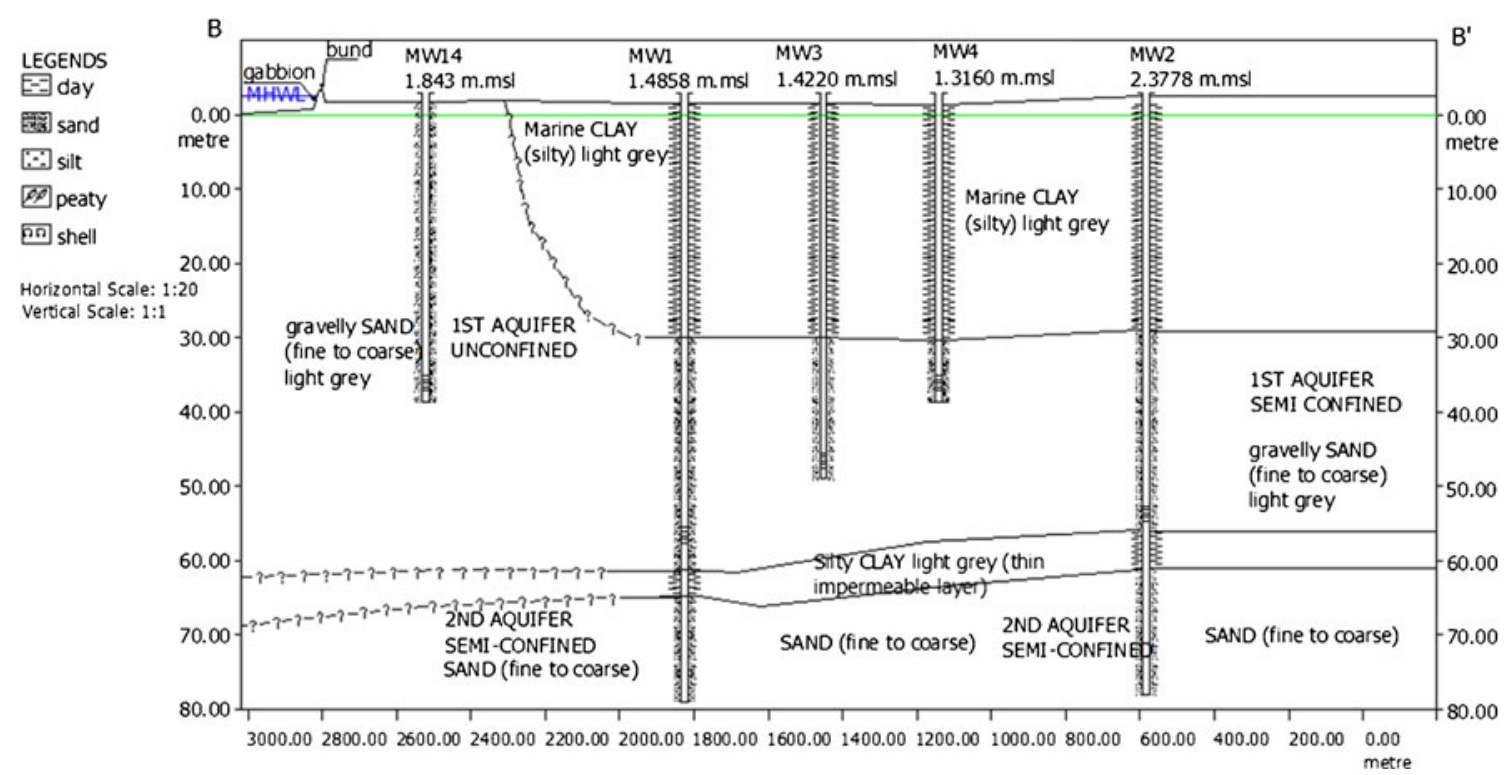

Fig. 6 Sub-surface profile of $B-B^{\prime}$ cross section shows unconfined and semi-confined aquifers in the area studied 


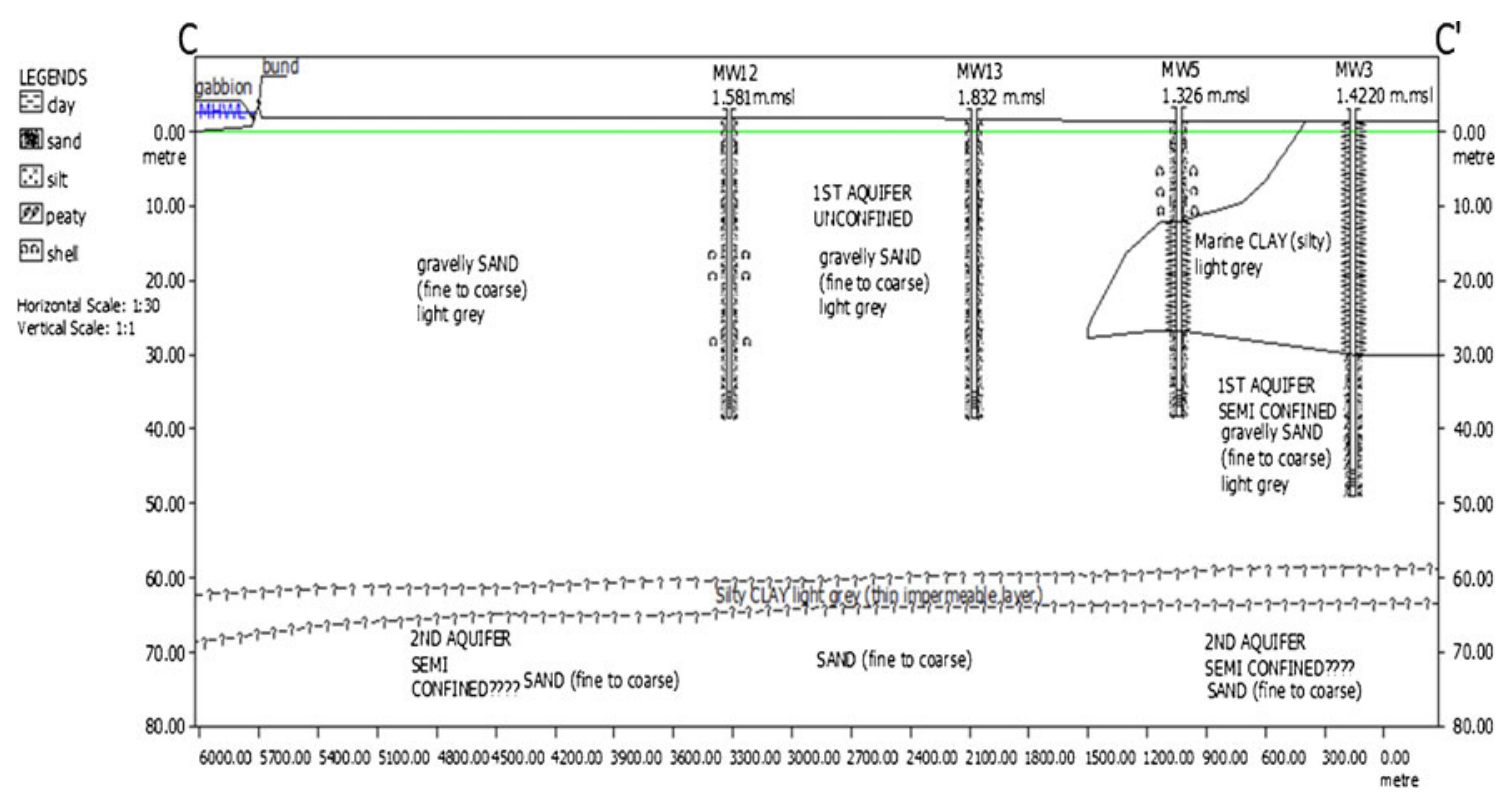

Fig. 7 Sub-surface profile $\left(C-C^{\prime}\right.$ cross section) of the area studied showing unconfined and semi-confined aquifers; note the shell fragments found at MW12 and MW5

between groundwater tables and TDS showed contrasting results in the southeast and northwest areas. Low groundwater tables revealed high TDS in the southeast area, with TDS values exceeding $20,000 \mathrm{mg} / \mathrm{l}$, whereas TDS values in the northwest area only reached $10,000 \mathrm{mg} / \mathrm{l}$. Thus, the TDS of groundwater in the southeast area was twice as high as that in the northwest. In terms of groundwater table's data, monitoring wells in the northwest area yielded average groundwater tables that were four times larger than those in the southeast, for both wet and dry seasons. Reduce levels for all wells showed relatively small changes of 1.5 to $1.8 \mathrm{~m}$ as the wells were located in the coastal plain. Assuming the levels for all the wells to be the same, a preliminary conclusion can be made that groundwater tables in the study area are influenced more by groundwater density than by elevation and pressure. It can be concluded that seawater intrusion on the southeast area is more dominant compared to northwest area. Mangrove deforestation in the southeast area is believed to be the factor contributing to the dominancy of seawater intrusion in this area. The data obtained from the TDS monitoring represented 34-36 m depths of the aquifer system that was spatially limited. To obtain a bigger picture of the seawater intrusion condition in this area, electrical imaging resistivity mapping was used.

Table 2 Results for hydro-geochemical analysis of groundwater; water samples taken on 30 May 2010

\begin{tabular}{|c|c|c|c|c|c|c|c|c|c|c|c|c|c|c|c|}
\hline Well/drain ID & $\mathrm{Na}$ & $\mathrm{Mg}$ & $\mathrm{Ca}$ & K & $\mathrm{Fe}$ & $\mathrm{Cl}^{-}$ & $\mathrm{SO}_{4}^{-}$ & $\mathrm{NO}_{3}^{-}$ & $\mathrm{Br}^{-}$ & $\mathrm{Fl}^{-}$ & $\begin{array}{l}\text { Total } \\
(\mathrm{mg} / \mathrm{l})\end{array}$ & $\begin{array}{l}\text { TDS } \\
(\mathrm{mg} / \mathrm{l})\end{array}$ & $\begin{array}{l}\text { Conductivity } \\
(\mathrm{mS} / \mathrm{cm})\end{array}$ & $\mathrm{NaCl} / \mathrm{TDS}(\%)$ & $\begin{array}{l}\text { Screen level from } \\
\text { ground surface }(\mathrm{m})\end{array}$ \\
\hline MW1 & 2,799 & 377 & 174 & 115 & 5 & 6,726 & 367 & $<1$ & $<1$ & $<1$ & 10,563 & 11,100 & 21.16 & 86 & $57-59$ \\
\hline MW2 & 1,860 & 299 & 143 & 89 & $<1$ & 5,872 & 45 & $<1$ & $<1$ & 46 & 8,354 & 8,450 & 17.53 & 92 & $57-59$ \\
\hline MW3 & 5,560 & 707 & 195 & 189 & $<1$ & 12,298 & 241 & $<1$ & $<1$ & $<1$ & 19,190 & 21,820 & 38.53 & 82 & $47-49$ \\
\hline MW4 & 5,236 & 683 & 179 & 189 & $<1$ & 9,624 & $<1$ & $<1$ & $<1$ & $<1$ & 15,911 & 20,940 & 33.58 & 71 & $34-36$ \\
\hline MW5 & 5,545 & 756 & 237 & 198 & $<1$ & 10,915 & $<1$ & $<1$ & $<1$ & $<1$ & 17,651 & 21,770 & 39.04 & 76 & $34-36$ \\
\hline MW6 & 2,959 & 259 & 81 & 128 & $<1$ & 4,560 & 227 & $<1$ & $<1$ & $<1$ & 8,214 & 10,410 & 18.26 & 72 & $34-36$ \\
\hline MW7 & 5,504 & 767 & 225 & 212 & $<1$ & 11,421 & 99 & $<1$ & $<1$ & $<1$ & 18,228 & 22,210 & 38.66 & 76 & $34-36$ \\
\hline MW8 & 4,868 & 517 & 144 & 177 & $<1$ & 8,348 & 65 & $<1$ & $<1$ & $<1$ & 14,119 & 17,960 & 25.93 & 74 & $47-49$ \\
\hline MW9 & 2,130 & 357 & 175 & 97 & $<1$ & 6,126 & 78 & $<1$ & $<1$ & $<1$ & 8,963 & 9,230 & 16.95 & 89 & $34-36$ \\
\hline MW10 & 4,756 & 495 & 98 & 129 & $<1$ & 15,670 & 159 & $<1$ & $<1$ & $<1$ & 21,307 & 24,650 & 43.58 & 83 & $34-36$ \\
\hline MW11 & 2,335 & 406 & 189 & 82 & $<1$ & 5,768 & 85 & $<1$ & $<1$ & $<1$ & 8,865 & 9,470 & 17.62 & 86 & $34-36$ \\
\hline MW12 & 2,408 & 189 & 75 & 106 & $<1$ & 3,486 & 183 & $<1$ & $<1$ & $<1$ & 6,447 & 8,330 & 14.09 & 71 & $34-36$ \\
\hline MW13 & 2,657 & 234 & 74 & 89 & $<1$ & 4,109 & 99 & $<1$ & $<1$ & $<1$ & 7,254 & 9,570 & 18.18 & 71 & $34-36$ \\
\hline
\end{tabular}


Fig. 8 Higher groundwater tables observed at MW 12, followed by MW13, MW6, MW 14, MW11, MW5, MW7 and MW10

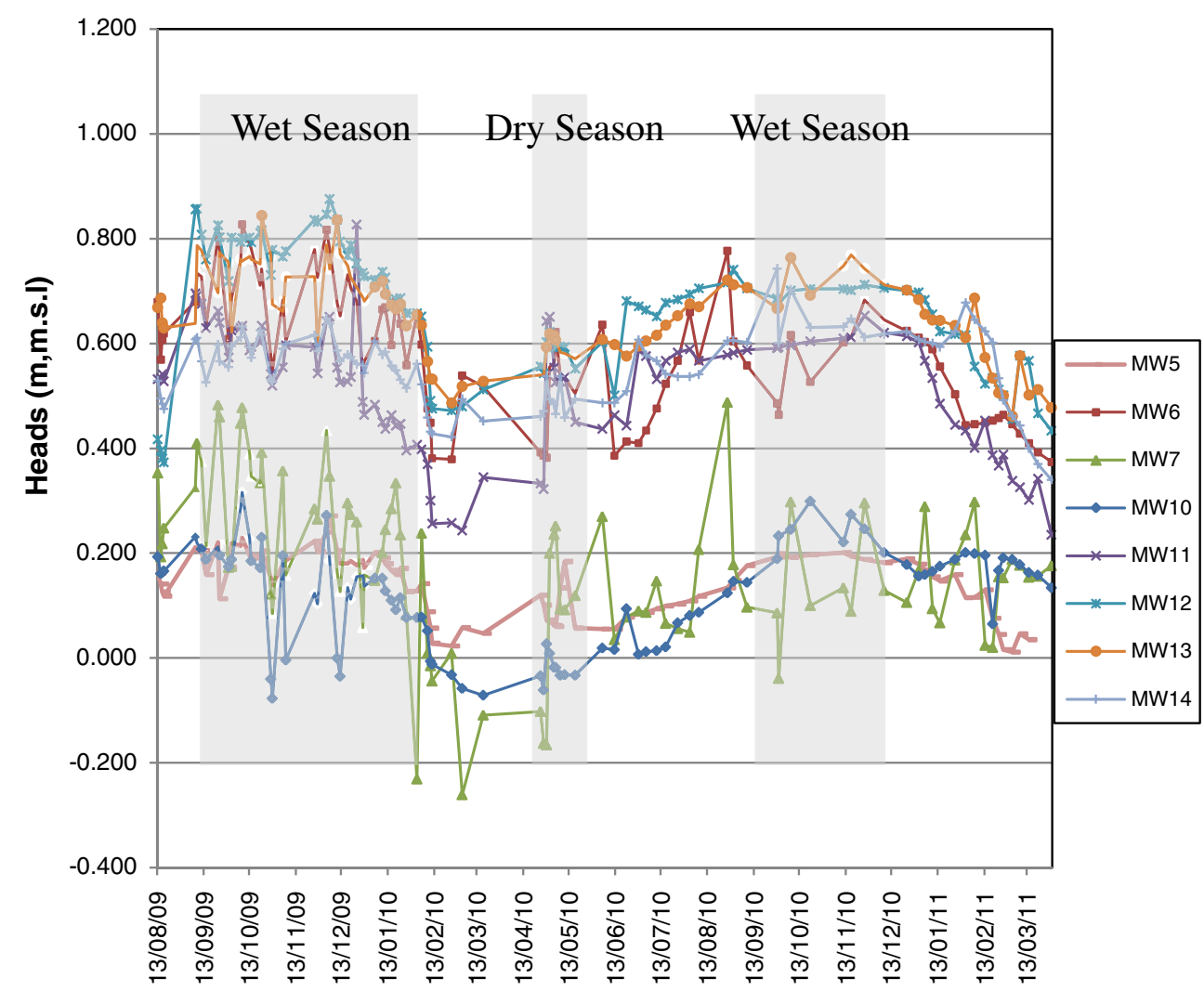

Date
Results of resistivity and correlations

Earth resistivity and groundwater quality data were used to determine the correlation of both parameters. Some of the images of the resistivity measurements conducted in August 2009, November 2009 and February 2010 in the study area are illustrated in Fig. 10a for profile L15-L15', Fig. 10c for profile L16-L16' and Fig. 10e for profile L7-L7'. More than $80 \%$ of the resistivity images show a low resistivity $(<3 \Omega$ $\mathrm{m}$ ), except for L7-L7' as shown in Fig. 10e. The resistivity profile values for L7-L7' ranged from 1.0 to $24.0 \Omega \mathrm{m}$. Resistivity values in other studies on coastal alluvial areas had a wider range of 0 to $1,000 \Omega \mathrm{m}$ (Wilson et al. 2006) and 0 to 2,500 $\Omega \mathrm{m}$ (Pujari and Soni 2008). Wilson et al. (2006) used a formation factor to derive bulk earth and pore-fluid resistivities to determine water types. Pujari and Soni (2008) limited the resistivity band from nearly 0 to $3.0 \Omega \mathrm{m}$ (interpreted as seawater intrusion). In Malaysia, Nawawi et al.
Fig. 9 Higher TDS values contradict with the sequent of higher groundwater tables in monitoring wells as shown in Fig. 8

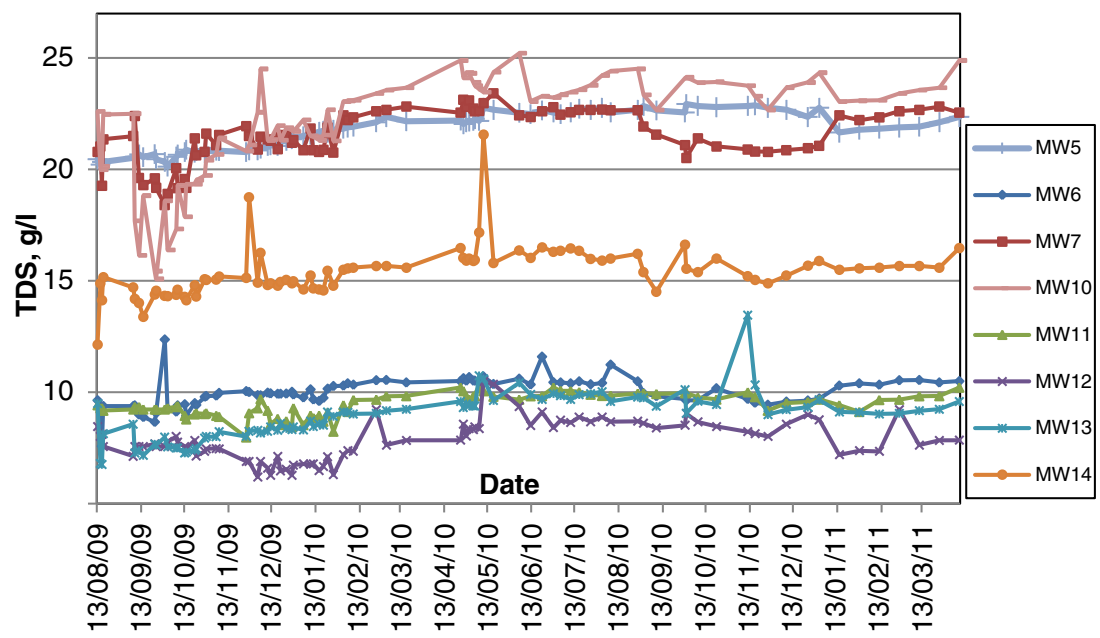


Fig. 10 Resistivity and conductivity images across various profiles

\section{L16’ South, Sea (15m)}

MW 7

Location: Profile L16-L16
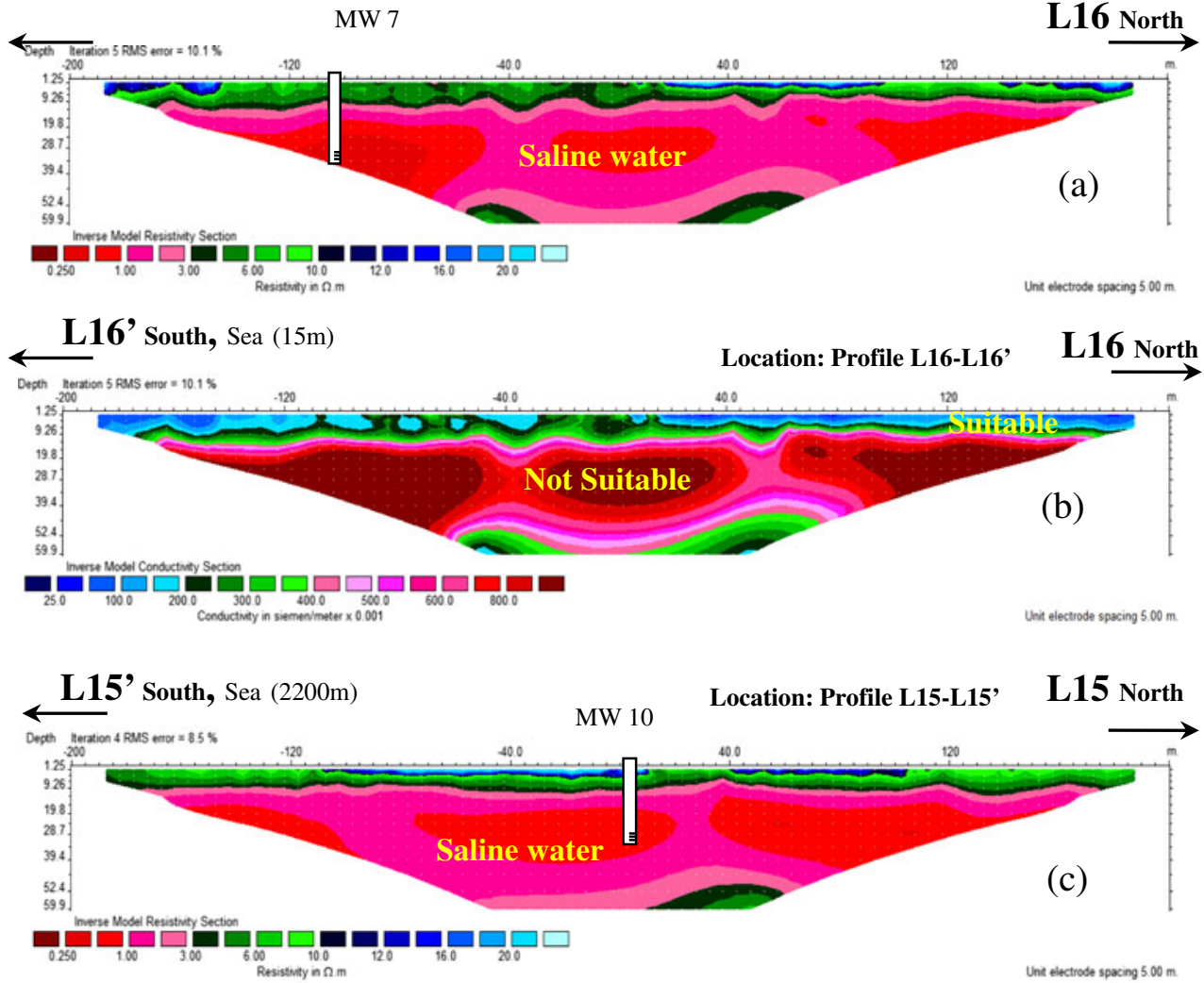

L15' South, Sea (2200m)

Location: Profile L15-L15'

L15 North

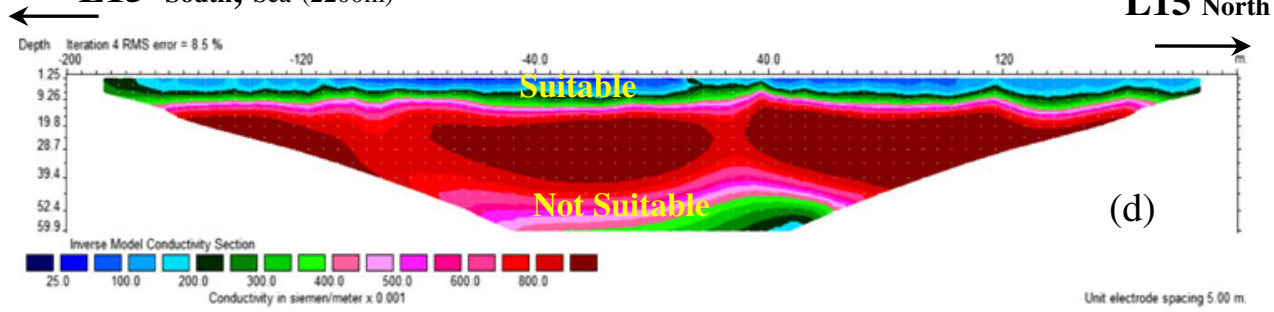

L7' South, Sea (1600m)

L7 North

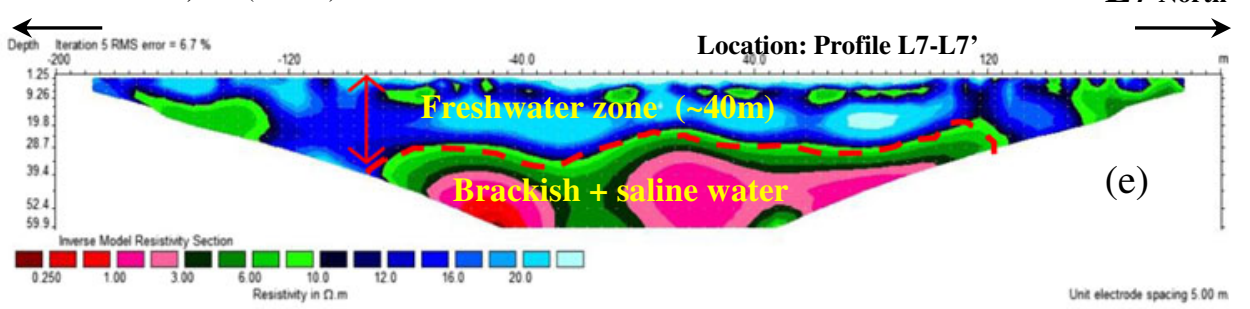

L7' South, Sea (1600m)

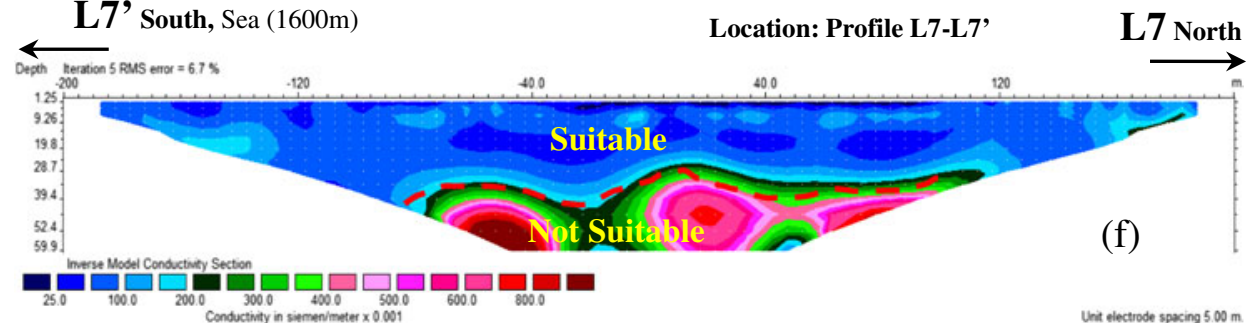


(2001) also used the resistivity technique in exploring aquifer properties and salt water intrusion in several parts of the western coast of Peninsular Malaysia. A sub-surface material with a resistivity of less than $5 \Omega \mathrm{m}$ was used for saline water. A similar study by Surip (1994) in the eastern coast of Peninsular Malaysia showed that the saline alluvial layer had a resistivity of less than $2 \Omega \mathrm{m}$. The conductivity inversion model of resistivity survey lines for profiles L15-L15', L16L16' and L7-L7' during measurement taken on December 2010 is demonstrated in Fig. 6b, d and f, respectively. The conductivity inversion model was derived by taking the inverse of the earth resistivity data $\left(\sigma_{s}=\frac{1}{\rho_{e}}\right)$ using the RES2DINV software. Preliminary assumptions were derived from the present study. Very low-resistivity values ( $\sim 0$ to 3.0 $\Omega \mathrm{m}$ ) were interpreted as an indication of a saline-water zone. Low-resistivity values (3.0 to $24.0 \Omega \mathrm{m}$ ) indicated a possible mix of freshwater and seawater in the pores. The alluvial quaternary comprised homogenous water-bearing sand and some gravel (both attributed to a large volume of pore fluids) contributing to the volumes of groundwater flowing through the pores. Hence, the resistivity measurements were probably more influenced by the pore fluid than by the mineral composition of the soil, causing the resistivity images of the water types to be more apparent. The concentration of dissolved ions in pore fluids is important for controlling the electricitytransmitting ability of groundwater (Sherif et al. 2006). The procedures for obtaining these relationships were as described by Cartwright and McComas (1968); Ebraheem et al. (1990) and Sherif et al. (2006). The specific conductance of the groundwater samples was converted into water resistivity $\left(\rho_{w}=\frac{1}{\sigma_{w}}\right)$. (Soil conductance was derived by taking the inverse of the earth-resistivity data $\left(\sigma_{s}=\frac{1}{\rho_{e}}\right)$. Ebraheem et al. (1997); Sherif et al. (2006) and Ebraheem et al. (2012) stated that an empirical relationship between geochemical and geophysical methods can be derived when ions are dissolved in pore fluids rather than in the host soil. This relationship was apparent in the electrical images. Previous findings on the use of the empirical relationship as shown by resistivity image data were used in the present study. For the empirical relationship between the geochemical and geophysical data, 24 geochemical and resistivity measurements were used (Table 3). The data were collected from nine deep monitoring wells and nine resistivity survey measurements on August 2009, November 2009 and February 2010. Water classification was based on Fetter (2002), and three types were identified as follows: saline (TDS $>10,000 \mathrm{mgl}^{-1}$ ), brackish $\left(1,000<\mathrm{TDS}_{1}<10,000 \mathrm{mgl}^{-1}\right)$ and fresh $\left(\mathrm{TDS}<1,000 \mathrm{mgl}^{-1}\right)$. By assuming the topography of the study area to be flat, the groundwater table measured from the reference ground surface table for all monitoring wells showed a high groundwater table within the range of 0.461 to $1.560 \mathrm{~m}$ (Table 3$)$. The inversion resistivity model (Fig. 6a, c and e) using the array Wenner configuration with an electrode spacing of $5 \mathrm{~m}$ showed a starting depth of $2.50 \mathrm{~m}$. Therefore, the inversion model images show a condition of saturation with water. The correlation between geochemical and geophysical data were determined in MW3 and MW4 located in the semi-confined aquifer with water-saturated sandy soil. The screen was at the sand layer of the first aquifer in the semi-confined zone. The screen for MW3 was located at a depth of 46 to $48 \mathrm{~m}$, whereas that for MW4 was placed at 34 to $36 \mathrm{~m}$. All data (Table 3) were used to obtain the empirical relationships between earth and water resistivities, TDS and specific water conductance, as well as TDS and earth resistivity.

The data in Table 3 were evaluated statistically using skewness, kurtosis and Pearson correlation coefficient $(r)$ to evaluate the distribution, as well as correlation, of the data used for deriving the empirical relationship using statistical analysis in Microsoft Excel 2010. The statistical analysis showed that the distribution of the data followed the normal distribution where the skewness and kurtosis value was nearly in the range of -1 to +1 .

Pearson correlation coefficient $(r)$ for all the data showed a strong linear relationship, which illustrated the value approach -0.9 to +0.9 , and can be used to derive a linear regression to determine the relationship between the data, especially earth resistivity versus water resistivity and earth resistivity versus TDS data.

Water resistivity was plotted as a function of earth resistivity (Fig. 11). The best regression line between water and earth resistivity indicated the following empirical relationship:

$\rho_{e}=6.4708 \rho_{w}-1.0488$

where $\rho_{e}$ is the earth resistivity and $\rho_{\mathrm{w}}$ is the water resistivity in ohm-meters.

Both parameters showed good correlations $\left(R^{2}=0.9593\right)$. This result reveals that the earth resistivity of a quaternary alluvium aquifer (consisting of dominantly coarse, medium and fine sand as well as some gravel) and of saturated groundwater affects salinity. The observations and analyses reaffirmed the basis for applying the geo-electrical method in studying the salinity distribution in the groundwater system of Carey Island.

Earth resistivity and TDS were also plotted (Fig. 12). The best regression line of the plot indicated the following empirical relationship:

$\log T D S=-0.1411 \rho_{e}+4.4286$

The relationship derived from Eq. (2) revealed that three types of groundwater can be depicted in the resistivity images, namely, fresh $\left(\rho_{\mathrm{e}}>10.0 \Omega \mathrm{m}\right)$, brackish $\left(3.0 \Omega \mathrm{m}<\rho_{\mathrm{e}}<10.0 \Omega \mathrm{m}\right)$ and saline $\left(\rho_{\mathrm{e}}<3.0 \Omega \mathrm{m}\right)$. 
Table 3 Geo-electrical and hydrogeological data used for empirical relationships between earth resistivity and water resistivity and between TDS and earth resistivity

\begin{tabular}{|c|c|c|c|c|c|c|c|c|}
\hline Well ID & $\begin{array}{l}\text { Sampling } \\
\text { (month) }\end{array}$ & $\begin{array}{l}\text { Groundwater table depth } \\
\text { referred from ground } \\
\text { surface }(\mathrm{m})\end{array}$ & $\begin{array}{l}\text { Groundwater table } \\
\text { depth referred from } \\
\text { mean sea level (m) }\end{array}$ & $\begin{array}{l}\text { Water } \\
\text { conductance } \\
(\mu \mathrm{mho} / \mathrm{cm})\end{array}$ & $\begin{array}{l}\text { Soil } \\
\text { conductance } \\
(\mu \mathrm{mho} / \mathrm{cm})\end{array}$ & $\begin{array}{l}\text { Water } \\
\text { resistivity } \\
(\Omega \mathrm{m})\end{array}$ & $\begin{array}{l}\text { Earth } \\
\text { resistivity } \\
(\Omega \mathrm{m})\end{array}$ & $\begin{array}{l}\text { Measured TDS } \\
((\mathrm{mg} / \mathrm{l})\end{array}$ \\
\hline MW3 & Aug-09 & 0.942 & 0.480 & 35,240 & 9,083 & 0.2838 & 1.101 & 21,410 \\
\hline MW5 & Aug-09 & 1.070 & 0.256 & 33,280 & 9,497 & 0.3005 & 1.053 & 20,330 \\
\hline MW6 & Aug-09 & 0.944 & 0.530 & 14,870 & 3,211 & 0.6725 & 3.114 & 8,940 \\
\hline MW7 & Aug-09 & 1.496 & 0.057 & 35,270 & 10,384 & 0.2835 & 0.963 & 21,190 \\
\hline MW8 & Aug-09 & 0.999 & 0.492 & 23,010 & 5,173 & 0.4346 & 1.933 & 13,810 \\
\hline MW10 & Aug-09 & 1.135 & 0.256 & 34,650 & 18,904 & 0.2886 & 0.529 & 21,060 \\
\hline MW11 & Aug-09 & 1.150 & 0.712 & 27,250 & 8,197 & 0.3670 & 1.22 & 16,620 \\
\hline MW12 & Aug-09 & 0.738 & 0.843 & 12,620 & 2,289 & 0.7924 & 4.368 & 7,660 \\
\hline MW3 & Nov-09 & 0.964 & 0.458 & 34,420 & 11,099 & 0.2905 & 0.901 & 21,090 \\
\hline MW4 & Nov-09 & 1.025 & 0.291 & 34,710 & 11,614 & 0.2881 & 0.861 & 21,420 \\
\hline MW6 & Nov-09 & 0.770 & 0.704 & 15,790 & 3,212 & 0.6333 & 3.113 & 9,750 \\
\hline MW7 & Nov-09 & 1.560 & -0.007 & 34,720 & 9,785 & 0.2880 & 1.022 & 21,480 \\
\hline MW8 & Nov-09 & 1.014 & 0.477 & 29,121 & 6,954 & 0.3434 & 1.438 & 18,050 \\
\hline MW10 & Nov-09 & 1.160 & 0.231 & 33,930 & 13,850 & 0.2947 & 0.722 & 20,690 \\
\hline MW11 & Nov-09 & 1.516 & 0.346 & 25,920 & 9,524 & 0.3858 & 1.05 & 16,120 \\
\hline MW3 & Feb-10 & 1.117 & 0.305 & 36,890 & 11,905 & 0.2711 & 0.84 & 21,680 \\
\hline MW4 & Feb-10 & 1.226 & 0.090 & 33,030 & 14,045 & 0.3028 & 0.712 & 19,430 \\
\hline MW5 & Feb-10 & 1.277 & 0.049 & 37,990 & 13,908 & 0.2632 & 0.719 & 22,350 \\
\hline MW6 & Feb-10 & 1.061 & 0.413 & 17,581 & 3,591 & 0.5688 & 2.785 & 10,340 \\
\hline MW7 & Feb-10 & 1.490 & 0.063 & 38,640 & 24,450 & 0.2588 & 0.409 & 22,800 \\
\hline MW10 & Feb-10 & 1.386 & 0.005 & 39,380 & 18,051 & 0.2539 & 0.554 & 23,250 \\
\hline MW11 & Feb-10 & 1.183 & 0.679 & 35,842 & 16,694 & 0.2790 & 0.599 & 21,090 \\
\hline MW12 & Feb-10 & 1.021 & 0.560 & 15,731 & 3,724 & 0.6357 & 2.685 & 9,220 \\
\hline
\end{tabular}

The relationship of formation resistivity to fluid conductivity depends on the sediment type and pore-water conductivity. Archie (1942) related the linear formation $\rho_{\mathrm{f}}(\Omega \mathrm{m})$ and pore-water resistivity $\rho_{\mathrm{w}}(\Omega \mathrm{m})$ in terms of the electrical conductivities $\sigma_{\mathrm{w}}$ and $\sigma_{\mathrm{f}}\left(\mathrm{Sm}^{-1}\right)$, as follows:

$\sigma_{w}=F \sigma_{f}$

where the proportionality constant $F$ is the formation factor related to sediment porosity. Equation (3) is valid for sediments whose matrix resistivity is high and the main conductor is pore water. Poulsen et al. (2010) mentioned that a significant amount of clay in soil sediment can be a significant conductor. Consequently, formation resistivity becomes a nonlinear function of pore-water conductivity, especially in freshwater with conductivities less than $0.5 \mathrm{Sm}^{-1}$.

The relationship between the geochemical and geophysical data derived from Eq. (2) was used for the unconfined aquifer system containing granular material saturated with

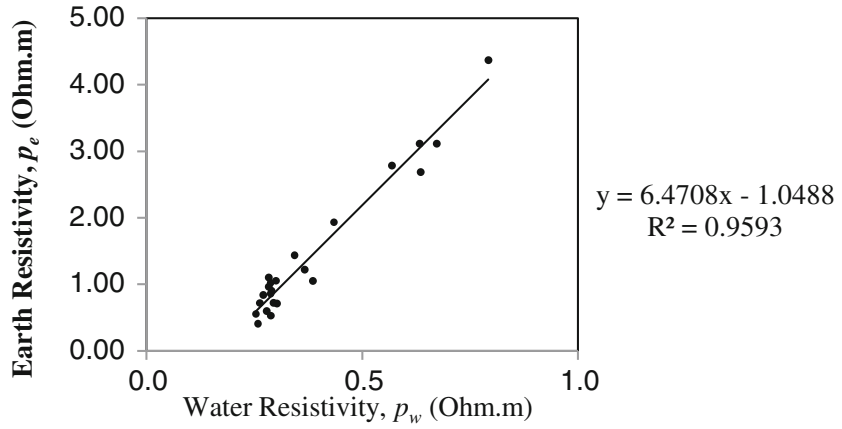

Fig. 11 Earth resistivity versus water resistivity

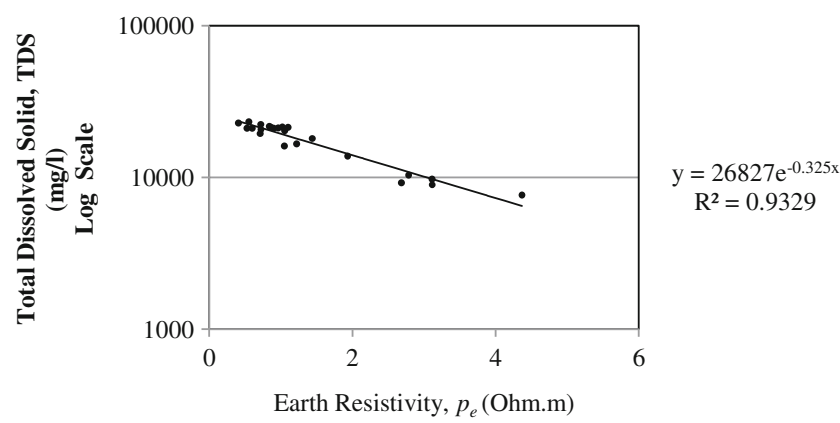

Fig. 12 Empirical relationship between TDS and earth resistivity 
water. For MW3 and MW4, the sub-surface profile showed a marine clay layer with a thickness of $30 \mathrm{~m}$ from the ground level. Equation (2) can only be used for depths ranging from 30 to $64 \mathrm{~m}$, which is still in the Gula Formation.

\section{Results of conductivity mapping and discussions}

The results of the conductivity contour mapping of the 17 conductivity inversion models based on the following classification of the suitability of oil palm plantation toward salinity $\left(C>0.4 \mathrm{Sm}^{-1}\right.$, suitable; $0.4 \mathrm{Sm}^{-1}<C<0.2 \mathrm{Sm}^{-1}$, moderately suitable; and $C<0.2 \mathrm{Sm}^{-1}$, not suitable) are illustrated in Fig. $13 \mathrm{a}-\mathrm{d}$.

The conductivity image at depths of $2.5 \mathrm{~m}$ (Fig. 13a) showed that almost $70 \%$ of the area with conductivity value of $0.2 \mathrm{Sm}^{-1}$ was suitable for oil palm plantation. The image also showed that some areas were moderately suitable and not suitable for plantation, especially along the main agricultural canal drainages and areas near the coast with unbund mangroves (see Fig. 2). On the southeast area with severe coastal erosion, the drainage flow into the main canal and the drain constantly containing freshwater were measured. The severe erosion in the area was mitigated by the construction of man-made bund and well-developed roads that prevented the penetration of seawater into the plantation surface soil. On the northwest area, the thicker mangrove forest prevented saline water intrusion into the plantation area. Saline water intrusion occurs during high tide when seawater floods the area. For the severely eroded area on the southeast area, the moderate conductivity condition $(0.2$ to $0.4 \mathrm{Sm}^{-1}$ ) appeared at a depth of $7.75 \mathrm{~m}$. On the northwest area, a similar depth was still suitable for oil palm plantation (Fig. 13b). The conductivity value not suitable for oil palm plantation was found at $14.1025 \mathrm{~m}$ depth (Fig. 13c) for the severely eroded area. In the northwest area, where mangrove forests still exist, the conductivity value still suitable for plantation was at $31.0 \mathrm{~m}$ depth (Fig. 13d).

The suitability classification for oil palm plantation can also be expressed using the TDS value. The conductivity value can be converted into TDS using Eq. (3). TDS values derived from Eq. (3) and the suitability classification for oil palm plantation in the area are listed in Table 4.

The TDS value $>11,908 \mathrm{mgl}^{-1}$ showed the unsuitable condition for the oil palm because this condition can kill the plant. For the unsuitable condition showed in Table 4, the TDS value is slightly higher than the water classification value of saline water $\left(\right.$ TDS $>10,000 \mathrm{mgl}^{-1}$ ) suggested by Fetter (2002). The suitable TDS value for oil palm (TDS $<5,286 \mathrm{mgl}^{-1}$ ) is half the value of the TDS for brackish water (1,000 to $\left.10,000 \mathrm{mgl}^{-1}\right)$ as suggested by Fetter (2002). For the unconfined system, the results of the conductivity map showed that the current condition is suitable and moderately suitable for oil palm plantation. Groundwater tables with low TDS values were found in the northwest area where mangrove forests remained intact, and a resulting dominance of fresh groundwater was likewise observed. This situation has resulted in different limitations of groundwater suitability based on salinity tolerances for oil palm plants. The prediction on the sea-level rise in the twenty-first century by IPCC (2007) will cause an increase in the seawater intrusion to the area. The local scenario sea-level rise prediction study shows that the mean sea-level rise rates at Port Klang (Fig. 1) using Special Report on Emissions Scenarios B1, A1B and A2 scenarios are $0.387 \mathrm{~m}$ based on the predicted slope from 2001 to 2100 (California Hydrologic Research Laboratory 2010).

The unconfined aquifer facing the severe erosion area (profile resistivity lines near MW7, MW10 and MW5) showed the groundwater level measured from the mean sea level with the value of 0 to $0.3 \mathrm{~m}$ with TDS value of $11,400 \mathrm{mgl}^{-1}$ ( salinity condition that can kill the oil palm) at the depth of $15 \mathrm{~m}$ from ground surface. Based on the Ghyben-Herzberg assumption, a $0.5-\mathrm{m}$ increase in the sea level will cause a 20-m reduction in the thickness of the freshwater storage. The assumption predicted this area to become unsuitable for oil palm plantation much earlier than the area on the northwest area which still has a mangrove forest. Furthermore, the root zone system of the oil palm can reach down 1 to $6 \mathrm{~m}$ where this zone is in the watersaturated condition with the high groundwater table between 0.738 and $1.560 \mathrm{~m}$ from ground level data (Table 3). Land transformation in this area, which shows severe coastal erosion especially in the southeast area, reduced the original level of the coastal surface. This phenomenon is believed to have changed the hydrogeology of the island, which constantly receives saltwater pressure. By contrast, in northwest areas that are still preserved with large-scale reversed mangrove areas, the geomorphology of the coastal area was sustained, and further intrusion of seawater to the inland was prevented. As highlighted by Bann (1998), mangroves act as the natural barrier to shoreline erosion, stabilising fine sediments (achieved by plant roots binding and stabilising the soil and the vegetative matter deposited), dissipating erosion forces (wave and wind) and trapping sediments as well as encouraging groundwater recharge. Groundwater recharge refers to movement (usually downward) of surface water into the groundwater flow system. Water moving from the mangrove to the aquifer can remain part of the shallow groundwater system, supplying water to the surrounding areas and sustaining the water table, or eventually moving into the deep groundwater system, a long-term water resource. Subsequently, mangroves can prevent seawater intrusion into groundwater supply systems (Bann 1998).

Reduction of freshwater storage can cause the reduction in the freshwater thickness of the groundwater system. This condition can become worse with the climate change effect 
Fig. 13 Conductivity

distribution relative to ground surface

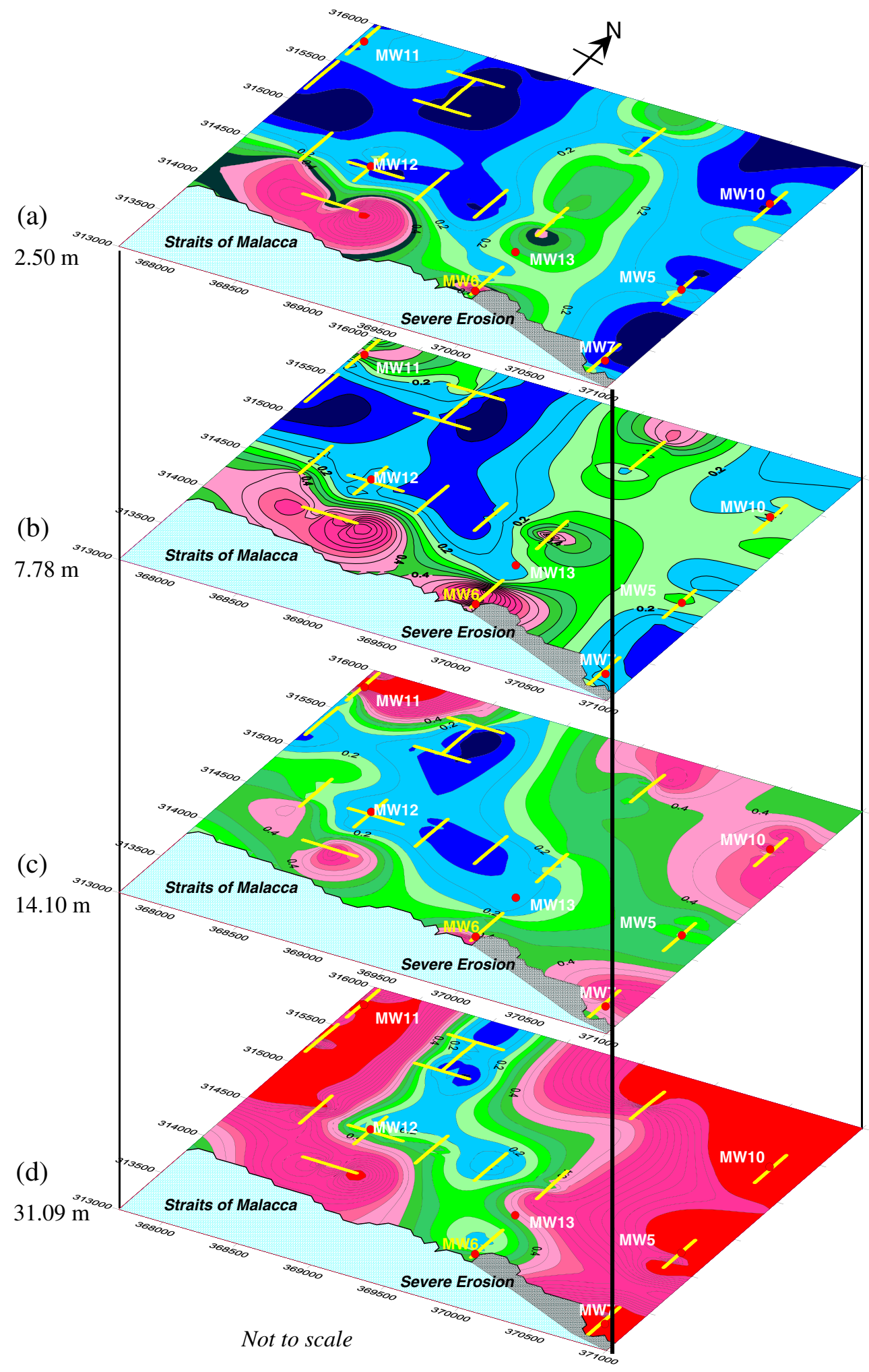

Conductivity (S/m)

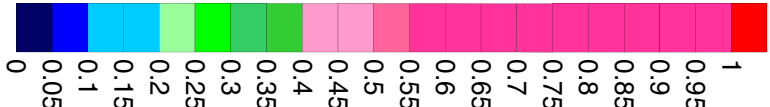


Table 4 TDS value for the suitability classification for palm oil plantation

\begin{tabular}{llll}
\hline $\begin{array}{l}\text { Conductivity (S/m) } \\
\begin{array}{c}\text { Sustainable status for } \\
\text { palm oil cultivation }\end{array}\end{array}$ & Suitable & $0.2 \mathrm{~S} / \mathrm{m}<C<0.4 \mathrm{~S} / \mathrm{m}$ & $C>0.4 \mathrm{~S} / \mathrm{m}$ \\
$\begin{array}{c}\text { TDS (mg/l) derived } \\
\text { from Eq. (3) }\end{array}$ & TDS $<5,286 \mathrm{mg} / 1$ & $5,286 \mathrm{mg} / \mathrm{l}<\mathrm{TDS}<11,908 \mathrm{mg} / \mathrm{l}$ & TDS $>11,908 \mathrm{mg} / 1$ \\
\hline
\end{tabular}

that reduces the precipitation (IPCC 2007) and subsequently can decrease recharge to the groundwater system (Carneiro et al. 2010). Regional hydrological climate model in Peninsular Malaysia (RegHCM-PM) has been developed in order to downscale the available global historical and climate change atmospheric databases that were produced by the Canadian global climate models at a coarse grid resolution of about $410 \mathrm{~km}$, to Peninsular Malaysia at a fine spatial resolution $(\sim 9 \mathrm{~km})$. Based on the RegHCM-PM results' projections, the study area shows that the greatest projected reduction in average annual rainfall is at $5 \%$ by 2050 (Kavvas et al. 2006). As aforementioned, groundwater recharge at Carey Island relies totally on local precipitation. Carey Island is believed to experience the worse decrease in the recharge because of climate change compared with the current condition. This condition can worsen with the high evapotranspiration rate of the matured oil palm (more than 8 years old) where the rate can reach up to 7.5 mmday $^{-1}$ plant $^{-1}$ during drought season, and the lifetime of an oil palm can reach 21 to 25 years (Soo 1991; Corley and Tinker 2003). Hence, the sustainability of oil palm plantation in Carey Island in the future will be reduced because of the climate change that is expected to induce a reduction of the fresh groundwater storage. The climate change is expected to increase the sea level and reduce precipitation that is the main source for the groundwater system refurbishment. The reduction of the freshwater storage will reduce and eliminate the quality of the groundwater suitable for the oil palm plantation in the future. However, further study can be conducted using numerical modelling together with diffuse model incorporating the existing hydrogeological parameters to predict the sustainability of the agricultural activity that will be affected by an increase in the sea level and elevated seawater intrusion to Carey Island.

\section{Conclusions}

Groundwater contamination is a serious issue as it leads to the depletion of fresh groundwater resources. Seawater intrusion is a groundwater contamination that affects socioeconomic activities, as it threatens sustainability including that of agriculture in coastal areas. The study uses an integrated method comprising of geo-electrical resistivity and hydro-geochemical methods at two different land cover conditions. They are areas affected by severe coastal erosion due to large-scale deforestation and area surrounded by preserved mangrove.

The finding of this study explained the differential groundwater quality and quantity at two different land cover scenarios, areas affected by severe coastal erosion due to large-scale deforestation and area surrounded by preserved mangrove. In the northwest area where mangrove forests remained intact, high heads with low TDS values were found and a resulting dominance of fresh groundwater is observed. Severe erosion in the southeast area caused by mangrove deforestation is a contributing factor to the increased of seawater intrusion in this area. Mangrove is critical to sustain freshwater condition of groundwater for agriculture at ex-promontory land as the groundwater system in this area largely relies on local precipitation. The conductivity mapping results showed that the unconfined aquifer thickness of the severe coastal erosion area will be more vulnerable to seawater intrusion due to sea level rise in the future. Based on the Ghyben-Herzberg assumption, it is predicted that this area will become unsuitable for oil palm plantation much earlier than the mangrove-preserved area which still has a mangrove forest.

Numerous theoretical studies assumed that the function of the mangrove is to increase the formation of freshwater lens and to prevent seawater intrusion without many case studies. The data and result from this study, including the size, distribution of freshwater and salinity of the groundwater, reemphasize these theoretical studies. They are crucial for the management of coastal area resources to ascertain the status of groundwater salinity for agriculture and particularly in Carey Island. The application of geo-electrical method combined with geochemical data, aided with the information on environmental history and oil palm physiography, has demonstrated that the integration of techniques is an effective tool in defining the status of agricultural suitability affected by salinity at the coastal aquifer area. The present study can also assist local authorities and villagers around the world, especially developing countries that rely on agriculture as main commodity, when planning the socioeconomics of an area by a thorough understanding of the salinity in soil and groundwater at the coastal areas. 
Acknowledgments The project has been made possible by a research grant provided by the Institute of Ocean and Earth Science (IOES) University Malaya, Kuala Lumpur, Malaysia.

\section{References}

Abd. Ghani E, Zakaria ZZ, Wahid MB (2004) Guidelines for palm oil industries, Perusahaan Sawit di Malaysia, Millennium Edition, Malaysian Palm Oil Board, Ministry of Plantation Industries \& Commodities, Malaysia. ISBN 967-961-096, 15

Abd-Elhamid HF (2010) A simulation-optimization model to study the control of seawater intrusion in coastal aquifers. University of Exeter, UK, PhD thesis, Unpublished

Abdul Nassir SS, Loke MH, Lee CY, Nawawi MNM (2000) Salt-water intrusion mapping by geoelectrical imaging surveys. Geophys Prospect 48(4):647-661. doi:10.1046/j.1365-2478.2000.00209.x, http:// web.ebscohost.com/ehost/pdf?vid=3\&hid=113\&sid=f505 $08 \mathrm{~d}$ d330-4dc5-99bo-df1909144ee2\%40sessionmgr109

Adepelumi A, Ako BD, Ajayi TR, Afolabi O, Omotoso EJ (2009) Delineation of saltwater intrusion into the freshwater aquifer of Lekki Peninsula, Lagos, Nigeria. Environ Geol 56(5):927-933. doi:10.1007/s00254-008-1194-3, http://www.spingerlink.com/ content/ekj1477561052r10/fulltext.pdf

Affandi, NAM, Kamali B, Rozainah MZ, Mohd Tamin N, Hashim R (2010) Early growth and survival of Avicennia alba seedlings under excessive sedimentation. Scientific Research and Essays, Vol. 5(18), ISSN 1992-2248, 2801-2805. http:// www.academicjournals.org/SRE. Accessed on 2 April 2011

APHA (2005) Standard methods for the examination of water and wastewater, 21st edn. American Public Health Association, Washington DC. ISBN 0-87553-047-8

Archie GE (1942) The electrical resistivity log as an aid in determining some reservoir charecteristics, Trans AIME Eng 146: 54-61. Available from: http://www.pe.tamu.edu/blasingame/data/z zCourse Archive/P663 03C/P663 03C TAB Ref FormEval/ SPE_Trans_1942_Archie_Reservoir_Char_from_Resistivity Logs.pdf. Accessed on 4 January 2011

Aris AH, Mohd Isa N (2012) Preliminary assessment on the hydrogeochemistry of Kapas Island Terengganu. Sains Malays 41 (1):23-32

Awni TB (2006) Use of electrical resistivity methods for detecting subsurface fresh and saline water and delineating their interfacial configuration: a case study of the eastern Dead Sea coastal aquifers, Jordan. Hydrogeol J 14:1277-1283. doi:10.1007/s10040006-0034-3, http://www.spingerlink.com/content/ 95613003427232r6/fulltext.pdf. Accessed 28 December 2008

Baba MF (2003) Geology quaternary at Teluk Datuk area, State of Selangor (sheet 101). Geology Quaternary Report, Department of Mineral and Geoscience Malaysia, Ministry of Natural Resources and Environment Malaysia, 1-32

Baharuddin MFT, Hashim R, Taib S (2009) Electrical imaging resistivity study at the coastal area of Sungai Besar Selangor Malaysia. J Appl Scie, ANSI 9(16):2897-2906. doi:10.3923/ jas2009.2897.2906, http://scialert.net/qredirect.php? doi $=$ jas.2009.2897.2906\&linkid $=$ pdf

Bann C (1998) The economic valuation of mangroves: a manual for researchers. International Development Research Centre, Ottawa, pp 1-54, EEPSEA Special Paper. http://www.eepsea.org/

Bear J, Cheng AH-D (2010) Seawater intrusion. In: Modeling groundwater flow and contaminant transport, theory and applications of transport in porous media. Vol 23. Springer, New York. doi:10.1007/978-1-4020-6682-5 9, http://www.spingerlink.com/ content/qkxx25qx83230021/fulltext. Accessed on 27 April 2010
Benkabbour B, Toto EA, Fakir Y (2004) Using DC resistivity method to characterize the geometry and the salinity of the Plioquaternary consolidated coastal aquifer of the Mamora plain, Morocco. Environ Geol 45(4):518-526. doi:10.1007/s00254-003-0906-y, Available from: http://www.spingerlink.com/content/ 3ejfg3cn4t89r141/fulltext.pdf

Berita Harian (2011) (Daily News) Berita Sawit, January 2011. Can be downloaded at http://www.mpob.gov.my/index.php? option $=$ com_content $\&$ view $=$ article $\&$ id $=1012 \% 3$ Aberita-sawit januari-2011\&catid=187\%3A2011\&lang=en. Official Portal for Malaysian Palm Oil Board (MPOB)

British Standard (BS) 1377 (1990) Part 2: method of test for soils for civil engineering purposes. British Standard Institution, London, pp 1-68. ISBN 0580178676

California Hydrologic Research Laboratory (2010) Final report for the study of the impact of climate change on sea level rise at Peninsular Malaysia and Sabah and Sarawak. California Hydrologic Research Laboratory, USA, p 96

Carneiro JF, Boughriba M, Correia A, Zarhloule Y, Rimi A, El Houadi B (2010) Evaluation of climate change effects in a coastal aquifer in Morocco using a density-dependent numerical model. Environ Earth Sci 61:241-252. doi:10.1007/s12665-009-0339-3, http:// www.springerlink.com/content/x220771285534647/fulltext.pdf

Cartwright K, McComas MR (1968) Geophysical surveys in the vicinity of sanitary landfills in northeastern Illinois. Ground Water 5:23-30, Available from: http://info.ngwa.org/GWOL/pdf/ 682578001.PDF

Corley RHV, Tinker PB (2003) The oil palm, 4th edn. Blackwell, Oxford, pp 1-562. ISBN 0-632-05212-0

Corley RHV, Hardon JJ, Wood BJ (1976) Developments in crop science. 1. Oil palm research. Elsevier, Amsterdam, pp 1-532 (Vol 1). ISBN 0-444-41471-1

Dahlin T, Loke MH (1998) Resolution of 2D Wenner resistivity imaging as assessed by numerical modelling. J Appl Geophys 38 (4):237-249, PII:50926-9851(97)00030-X. http://www.science direct.com/science? ob=MImg\& imagekey=B6VFC-35x52998-1\&-cdi=60078_user $=15079$. Accessed 8 January 2009

Department of Statistics Malaysia (2010) Yearbook of Statistics Malaysia 2009. Department of Statistics, Malaysia, pp 1-367, ISSN 0127-2624

Dey A, Morrison HF (1979) Resistivity modelling for arbitrarily shaped two-dimensional structures. Geophys Prospect 27(1):106136. doi:10.1111/j.1365-2478.1979.tb00961.x, http://www3. interscience.wiley.com/user/ID $=119598599 \&$ Act $=21388$ code $=4726 \&$ Page $=/$ cgi-bin/fulltext $/ 11$. Accessed 8 January 2009

Di Sipio E, Galgaro A, Zuppi GM (2006) New geophysical knowledge of groundwater systems in Venice estuarine environment. Estuarine Coastal Shelf Sci 66:6-12. doi:10.1016/ j.ecss.2005.07.015, http://www.sciencedirect.com/science? $\mathrm{ob}=\mathrm{MImg} \&$ imagekey=B6WDV-4H6PKWO-1-H\&cdi=67768 user $=15079$. Accessed 6 January 2010

Ebraheem AM, Hamburger MW, Bayless ER, Krothe NC (1990) A study of acid mine drainage using earth resistivity measurements. Ground Water 28(3):361-368, http://info.ngwa.org/GWOL/pdf/ 901550570.PDF. Accessed 6 January 2010

Ebraheem AM, Senosy MM, Dahab KA (1997) Geoelectrical and hydrogeochemical studies for delineating groundwater contamination due to saltwater intrusion in the northern part of the Nile Delta, Eygpt. Ground Water 35(2):216-222, http://info.ngwa.org/ GWOL/pdf/971262673.PDF. Accessed 6 January 2010

Ebraheem AM, Sherif MM, Al Mulla MM, Akram SF, Shetty AV (2012) A geoelectrical and hydrogeological study for the assessment of groundwater resources in Wadi Al Bih, UAE. Environmental Earth Science, in press. doi:10.1007/s12665-012-1527-0. http://www.springerlink.com/content/1308v2q248w76134/ fulltext.pdf 
Edet AE, Okereke CS (2001) A regional study of saltwater intrusion in southeastern Nigeria based on the analysis of geoelectrical and hydrochemical data. Environ Geol 40:1278-1289. doi:10.1007/s002540100313, http://www.springerlink.com/ content/9ayfk79gu16xp5yw/fulltext.pdf

Fairhurst TH, Hardter R (2003) Oil palm: management for large and sustainable yields. Potash \& Phosphate Institute (PPI)/ Potash \& Phosphate Institute of Canada (PPIC) and International Potash institute (IPI), 1st edn, ISBN 981-04-8485-2. pp $1-382$

Fetter CW (2002) Applied hydrogeology, 4th edn. Prentice-Hall, Englewood Cliffs, pp 1-598. ISBN 0131226878

Golden Hope Plantation Berhad (2006) Carey Island; a golden heritage; reliving history, preserving legacy. Golden Hope Plantation Berhad, ISBN 967-969-547-6. 1-16

Hamzah U, Yaacup R, Samsudin AR, Ayub MS (2006) Electrical imaging of the groundwater aquifer at Banting, Selangor, Malaysia. Environ Geol 49(8):1156-1162. doi:10.1007/s00254-0050160-6, Available from: http://www.spingerlink.com/content/ r8q5880065u3857/fulltext.pdf. Accessed 4 January 2009

Hiscock K (2005) Hydrogeology principles and practise. Blackwell, Oxford, p 244. ISBN 0-632-05763-7

IPCC (1996) Climate change 1995: the science of climate change: contribution of working group I to the second assessment report of the Intergovernmental Panel on Climate Change. Houghton, J. T., Meira Fihlo, L. G., Callander, B. A., Harris, N., Kattenberg, A. and Maskell, K. Cambridge University Press, Cambridge, UK and New York, NY, USA. http://www.ipcc.ch/ipccreports/sar/wg_I/ ipcc_sar_wg_I full_report.pdf

IPCC (2001) Climate change 2001: impacts, adaptations, and vulnerability. Contribution of working group II to the third assessment report of the Intergovernmental Panel on Climate Change. McCarthy, J. J., Canziani, O. F., Leary, N. A., Dokken, D. J. and White, K. S. Cambridge University Press, Cambridge, UK and New York, NY, USA. http://www.grida.no/publications/other/ipcc_tar/

IPCC (2007) Climate change 2007: impacts, adaptations, and vulnerability. Contribution of working group II to the fourth assessment report of the Intergovernmental Panel on Climate Change. Cambridge University Press, Cambridge (can be download at: http:// www.ipcc.ch/publications_and_data/publications_ipcc_fourth assessment report wg2 report impacts adaptation and vulnerability.htm)

Ismail R (2008) Construction and exploration of deep wells at Carey Island and $\mathrm{Kg}$ Kelanang, Kuala Langat District, Banting Selangor. National Groundwater Resources Study under Subproject groundwater resources for State of Selangor. Report done by KS Global Sdn Bhd with collaboration Multical Card (M) Sdn Bhd under instruction the Department of Mineral and Geoscience Selangor State, Malaysia

JICA and MDGM (2002) The study on the sustainable groundwater resources and environmental management for the Langat Basin in Malaysia. Japan International Cooperation Agency (JICA) and Mineral and Geoscience Department Malaysia (MDGM) Report, Vol 3

Kavvas ML, Chen ZQ, Ohara N (2006) Study of the impact of climate change on the hydrologic regime and water resources of Peninsular Malaysia (final report). California Hydrologic Research Laboratory, Davis, http://www.nahrim.gov.my/download/pksa/ RegHCM_PM_Report_9_21_06_Ex\%20v1.pdf

Khalil MA, Abbas AM, Santos FM, Masoud U, Salah H (2012) Application of VES and TDEM techniques to investigate seawater intrusion in Sidi Abdel Rahman area, northwestern coast of Egypt. Arabian Journal of Geosciences. doi: 10.1007/s12517-012-0564-2. http://www.springerlink.com/content/704w27844vx2u036/ fulltext.pdf

Loke MH (2000) Electrical imaging surveys for environmental and engineering studies: a practical guide to 2-D and 3-D surveys.
Available online at www.geoelectrical.com/downloads.php. pp $1-60$

Loke MH (2010a) Tutorial: 2-D and 3-D electrical imaging surveys. Available online at www.geoelectrical.com/downloads.php. 1-145

Loke MH (2010b) RES2DINV ver. 3.59 for Windows XP/Vista/7 for Rapid 2-D Resistivity and IP Inversion using the least squares method. http://www.geoelectrical.com/downloads.php. $1-148$

Loke MH, Barker RD (1996) Rapid least squares inversion of apparent resistivity pseudosection using a quasi-Newton method. Geophys Prospect 44(3):131-152, GPPRAR44(1)1-178(1996). ISSN 0016-8025

Loke MH, Acworth I, Dahlin T (2003) A comparison of smooth and blocky inversion methods 2-D electrical imaging surveys. Explor Geophys 34(3):182-187, http:/www.geoelectrical.com/ downloads.php and email to mhloke@tm.net.my

Maillet GM, Rizzo E, Revil A, Vella C (2005) High resolution electrical resistivity tomography (ERT) in a transition zone environment: application for detailed internal architecture and infilling processes study of a Rhone River paleo-channel. Mar Geophys Res 26:317-328. doi:10.1007/s11001-005-3726-5, Available from: http://www.spingerlink.com/content1y1x7m7247q5x40p6/ fulltext.pdf. Accessed 6 January 2010

Malaysian Palm Oil Board (MPOB), 2010a, Review of the Malaysian oil palm industry 2009. Economic and Industry Development Divison MPOB, ISSN 1511-7488, pp 1-98

Malaysian Palm Oil Board (MPOB) (2010b) Malaysian Oil Palm Statistics 2009, 29th edition. Malaysian Palm Oil Board, Ministry of Plantation Industries \& Commodities, Malaysia, pp 1-198. ISSN 1511-743X

Mohd. Hashim G (2003) Salt-affected soils of Malaysia. A report prepared for the Food and Agriculture Organisation of the United Nations (FAO). Can be downloaded at: ftp://ftp.fao.org/agl/agll/ ladadocs/malaysia.doc, 1-34

Nawawi MNM, Harith ZZT, Ayub MS, Ibrahim AN, Alphonse A (2001) Modeling of an undergroundwater aquifer using 2D electrical imaging technique in Brooklands Plantation, Selangor, Malaysia. In: Proceedings of the second international symposium on geophysics, Egypt, 293-297

Ngah DS (1988) Groundwater investigation for determination of suitability using hand-pump at rural area of Kuala Langat District, Selangor Darul Ehsan, Report No. GPH1/1988. Department of Mineral and Geosciences Malaysia, Ministry of Natural Resources and Environment

Omar I, Ismail S, Omar W, Abu Bakar H (2010) National proceeding conference for small scale planters of palm oil 2010. Malaysian Palm Oil Board, Ministry of Plantation Industries \& Commodities, Malaysia, ISBN 978-967-961170-0, pp 1-226

Poulsen SE, Rasmussen KR, Christensen NB, Christensen S (2010) Evaluating the salinity distribution of a shallow coastal aquifer by vertical multielectrode profiling (Denmark). Hydrogeol J 18:161-171. doi:10.1007/s10040-009-0503-6, http:// www.springerlink.com/content/h1362g6228613458/fulltext.pdf, Accessed on 30 October 2010

Pujari PR, Soni AK (2008) Sea water intrusion studies near Kovaya limestone mine, Saurashtra coast, India. Environ Monit Assess 154(1-4):93-109. doi:10.1007/s10661-008-0380-9, Available from: http://www.spingerlink.com/content/5w365533728128x2/ fulltext.pdf. Accessed 6 January 2010

Samsudin AR, Haryono A, Hamzah U, Rafek AG (2008) Salinity mapping of coastal groundwater aquifers using hydrogeochemical and geophysical methods: A case study from north Kelantan, Malaysia. Environ Geol 55(8):1737-1743. doi:10.1007/s00254007-1124-9, Available from: http://www.spingerlink.com/content/ 6865279tg71287u5/fulltext.pdf. Accessed 3 January 2009 
Sathish S, Elango L, Rajesh R, Sarma VS (2011) Assessment of seawater mixing in a coastal aquifer by high resolution electrical resistivity tomography. Int J Environ Sci Tech 8(3):483-492, ISSN:1735-1472. http://www.ijest.org/jufile?c2hvd1BER j00OTc $=\& o b=21 \mathrm{c} 1 \mathrm{~b} 0 \mathrm{~b} 6 \mathrm{c} 9 \mathrm{ad} 046 \mathrm{f} 5 \mathrm{fc} 53584 \mathrm{f} 9143 \mathrm{f} 30 \&$ fileName $=$ full_text.pdf

Sherif M, El Mahmoudi A, Garamoon H, Kacimov A, Akram S, Ebraheem A, Shetty A (2006) Geoelectrical and hydrogeochemical studies for delineating seawater intrusion in the outlet of Wadi Ham, UAE. Environ Geol 49(4):536-551. doi:10.1007/s00254005-0081-4, http://www.spingerlink.com/content/ 7w07144t21663226/fulltext.pdf. Accessed 4 January 2009

Sikandar P, Bakhsh A, Arshad M, Rana T (2010) The use of vertical electrical sounding resistivity method for the location of low salinity groundwater for irrigation in Chaj and Rachna Doabs. Environ Earth Sci 60:1113-1129. doi:10.1007/s12665-009-0255-6, http:// www.springerlink.com/content/234248866242342v/fulltext.pdf. Accessed 10 April 2012

Soo FS (1991) Potential evapotranspiration, potential yield and leaching losses of oil palm, Research Development, Felda Agency, Vol 17, ISSN 0127-9564. 4-5

Suntharalingam T, Teoh LH (1985) Quaternary geology of the coastal plains of Taiping. Quaternary Geology Report. Geological Survey Malaysia. Ministry of Primary Industries Malaysia

Surip N (1994) Application of geophysical methods, hydrogeology and radioisotope for detecting saltwater intrusion into aquifer at Kuala
Rompin and Marang, West Peninsular Malaysia. Unpublished MSc theses National University of Malaysia

Tahir H, Abdul Hamid I (2003) The study of groundwater resource at Teluk Gong, Pelabuhan Kelang, Selangor Darul Ehsan. Report No. JMG.SWP (HG) 03/2003. Department of Mineral and Geosciences Malaysia, Ministry of Natural Resources and Environment

Tinker PB (1976) Soil requirements of the palm oil (Chapter 13), Developments in crop science. 1. Oil palm research. Elsevier, Amsterdsam, pp 165-181 (Vol 1). ISBN 0-444-41471-1

Været L, Kelbe B, Haldorsen S, Taylor RH (2009) A modelling study of the effects of land management and climatic variations on groundwater inflow to Lake St Lucia, South Africa. Hydrogeol J 17:1949-1967. doi:10.1007/s10040-009-0476-5, http:// www.springerlink.com/content/k6n481h1p76x14p2/fulltext.pdf

Williams CN, Hsu YC (1979) Oil palm cultivation in Malaya: technical and economic aspects. University of Malaya Press, Kuala Lumpur, pp 1-190

Wilson SR, Ingham M, McConchie JA (2006) The applicability of earth resistivity methods for saline interface definition. J Hydrol 316:301312. doi:10.10161j.jhydrol.2005.05.004, http://www.sciencedirect. $\mathrm{com} /$ science?-ob=MImg\&_imagekey=B6V6C-4GFCR6N-4-R\&_ cdi $=5811 \&$ user $=15079$. Accessed 6 January 2010

Wong IFT (1986) Soil-crop suitability classification for Peninsular Malaysia (Revised). Soils and Analytical Services Bulletin no. 1. Department of Agriculture, Ministry of Agriculture Kuala Lumpur, Malaysia. 9 